\title{
Biogeochemical Cycling in Forest and Rangeland Soils of the United States
}

\author{
Lindsey E. Rustad, Jennifer Knoepp, Daniel D. Richter, \\ and D. Andrew Scott
}

\section{Introduction}

In the Sand County Almanac (Leopold 1949), Aldo Leopold writes of the odyssey of element $\mathrm{X}$ and thus of the circulation of all nutrient elements as they cycle through the Earth's forests, rangelands, lakes, and oceans:

\begin{abstract}
The break came when a bur-oak root nosed down a crack and began prying and sucking. In the flush of a century the rock decayed, and $\mathrm{X}$ was pulled out and up into the world of living things. He helped build a flower, which became an acorn, which fattened a deer, which fed an Indian, all in a single year. From his berth in the Indian's bones, $\mathrm{X}$ joined again in chase and flight, feast and famine, hope and fear. He felt these things as changes in the little chemical pushes and pulls that tug timelessly at every atom. When the Indian took his leave of the prairie, $\mathrm{X}$ moldered briefly underground, only to embark on a second trip through the bloodstream of the land.
\end{abstract}

Also in mid-century, G.E. Hutchinson, while always one to praise aesthetic values, commented disparagingly about the quantitative science of element cycling, specifically that ecosystem carbon (C) data were "wretchedly inadequate" (Hutchinson 1954). Hutchinson's comment was not only a complaint but also a challenge to all ecosystem scientists who followed to quantify the Earth's biogeochemical cycles, for he understood that the resilience and functioning of ecosystems was entirely dependent on how plants, animals, and

L. E. Rustad $(\bowtie)$

U.S. Department of Agriculture, Forest Service, Northern Research Station, Center for Research on Ecosystem Change,

Durham, NH, USA

e-mail: Linsey.rustad@usda.gov

J. Knoepp

U.S. Department of Agriculture, Forest Service, Southern Research Station, Otto, NC, USA

D. D. Richter

Nicholas School of the Environment, Duke University,

Durham, NC, USA

D. A. Scott

U.S. Department of Agriculture, Forest Service, Bankhead

National Forest, Double Springs, AL, USA decomposers used and reused the chemical elements that we call nutrients.

In the late twentieth century, the science of biogeochemistry proliferated internationally to become a major interdisciplinary science, and enormous amounts of nutrient cycling data have since been collected and synthesized. Scientists recognized that the fundamental unit in ecology is the ecosystem, a dynamic, indivisible system of biota and the abiotic environment, and that elements cycle into, through, and out of these systems in generally predictable ways (Duvigneaud and Danaeyer-de Smet 1970; Likens and Bormann 1995; Ovington 1962). Many scientists followed Hutchinson's lead and were excited that forest and rangeland ecosystems conserve nutrients and recycle large fractions of the nutrients taken up each year by plant roots (Cole and Rapp 1981; Stone 1975; Switzer and Nelson 1972; Vitousek 1982; Wells et al. 1972).

Through this early body of work, it was quickly learned that individual nutrients cycle differently through ecosystems. Atmospheric inputs of the mineral elements nitrogen $(\mathrm{N})$ and sulfur (S) were found to be substantial, and these elements accumulated in the system over time. Mineralization of soil organic matter is the major immediate source of N, S, and boron (B) and, in some soils, is also the major source of phosphorus $(\mathrm{P})$. The soil's cation exchange capacity and the weathering of primary and secondary soil minerals are the most important sources for calcium $(\mathrm{Ca})$, potassium $(\mathrm{K})$, magnesium $(\mathrm{Mg})$, and many trace elements such as iron $(\mathrm{Fe})$, copper $(\mathrm{Cu})$, and zinc $(\mathrm{Zn})$. Overall, soil proved to be the major reservoir of nutrients for plant uptake and for the decomposition system that mineralizes and transformes organic matter, ensuring continued supplies of bioavailable nutrients. Ecosystems were known to lose nutrients through leaching losses to surface waters, gaseous losses to the atmosphere, and erosional losses. However, despite these losses, the biogeochemical cycles of forests were found to be generally conservative, such that the annual uptake of many nutrients, including N, P, S, B, and $\mathrm{K}$ (i.e., those used to drive photosynthesis in plants), was rapidly returned to the soil in aboveground and belowground 
litter inputs (Gosz et al. 1972; Prescott 2002; Vogt et al. 1986), thereby remaining within the ecosystem. The woody biomass of trees accumulates only a small fraction of most nutrients taken up from soil (Switzer and Nelson 1972). Examples of biogeochemical pools and fluxes for N, P, and Ca for representative ecosystems are provided in Fig. 4.1, which illustrates the range in biogeochemical cycling of these elements in forests and grasslands of the United States.

While the soil is a reservoir of nutrients, this store is often unable to supply nutrients at rates that meet the biological potential of the vegetation. In other words, the productivity of many of the forests and rangelands of the United States is nutrient-limited (Binkley and Fisher 2012) or may become nutrient-limited if soils are degraded by land uses (Richter Jr. and Markewitz 2001). Understanding these limitations is important when assessing the uses of forests and rangelands and how they function to provide food and fiber, clean and plentiful water, $\mathrm{C}$ sequestration, wildlife habitat, recreation, and reservoirs for biodiversity. Many millions of hectares of industrial forest in the United States are intentionally fertilized, mainly with $\mathrm{N}$ and $\mathrm{P}$, to boost productivity to its full potential (Fox et al. 2007). Many more millions of hectares also receive high amounts of point and nonpoint source pollutants, which unintentionally alter inputs or removals of nutrients at rates that are biologically significant and can impact forest and rangeland function (Buol et al. 2011; Richter Jr. and Markewitz 2001).

Soils and soil nutrient cycles vary greatly in space and are dynamic through time. Variations in space are better quantified in the literature than variations in time. Explanations for localto continental-scale spatial variations are well studied and can be attributed to multiple soil forming factors, including human actions (Jenny 1980; Richter and Yaalon 2012). These factors include interactions of climate, biota, geomorphology, substrates, and human impacts, as they all influence soils over time. Spatial variations in soil properties can be extreme at local scales (due to drainage classes), regional scales (due to soil series), and continental scales (due to soil order) (Fig. 4.2).

Soil physical, chemical, and biological processes play out over timescales that range from milliseconds to millennia (Fig. 4.3). Most soils are now recognized to be polygenetic, which means that soils have long enough residence times to have been exposed to and influenced by varying soil forming processes, including changing climate, vegetation, and human management (Richter and Yaalon 2012). Human imprints on forest and rangeland soils and nutrient cycles, including impacts from agriculture, forestry, industrialization, and urbanization, have been increasing in intensity and extent during the last century and are shaping soils in potentially novel ways (Richter 2007).

To investigate soil forming processes across time, many studies have substituted space for time in a classic chronosequence approach that can tell investigators the general direc- tion of temporal soil change (Hotchkiss et al. 2000). Perhaps the most well-known of these is the 2-My soil chronosequence on the Mendocino Staircase in California, where soils evolve from Entisols and Mollisols to Alfisols and their more acidic relatives the Ultisols and, finally, to extremely acidic Spodisols (Jenny 1980). At shorter timescales, localand landscape-scale heterogeneity limits the precision and accuracy of such space-for-time approaches (Buol et al. 2011; Richter Jr. and Markewitz 2001), and researchers rely instead on a remarkably few long-term field studies that directly observe time-dependent soil changes by repeated soil sampling. In an inventory of well over 200 long-term field studies worldwide, about $15 \%$ are studies of forest and rangeland soils (Richter and Yaalon 2012). These field studies demonstrate that soil is highly responsive to management and that the soil system is highly dynamic on decadal timescales (Mobley et al. 2015).

\section{Human Impacts on Forest and Rangeland Biogeochemical Cycling in the United States}

Nutrient cycling in forest and rangeland soils is highly malleable and can be impacted positively or negatively by human-caused disturbances. Active forest and rangeland management, by definition, manipulates aboveground and belowground $\mathrm{C}$ and nutrient cycles to achieve economic, recreational, or conservation goals or combinations of these goals. Timber harvesting, grazing, changes in species composition, fertilization, and prescribed fire all have direct and indirect impacts on nutrient pools and cycles. Modern civilization and associated industrialization and urbanization impose further alterations on these processes. Examples include point and nonpoint source pollutants; anthropogenicdriven changes in climate and the frequency and severity of extreme weather events; changes in distribution of invasive species, pests, and pathogens; and extreme disturbances such as wildfires, fracking, mining, and urbanization.

\section{Harvest and Grazing}

Forest harvesting and rangeland grazing can potentially affect nutrient cycling in many ways, including the direct removal of aboveground nutrients in the harvested or grazed material, redistribution of nutrient-rich material from aboveground vegetation to the soil surface, disruption of the hydrologic cycle due to reduction in evapotranspiration, reductions in plant nutrient uptake, increased leaching loss of nutrients to surface waters, and adverse impacts of soil compaction and erosion. The impacts of forest harvest on soil $\mathrm{C}$ and $\mathrm{N}$ have been examined in detail across the United States and elsewhere. Nave and others (2010) synthesized the results from 


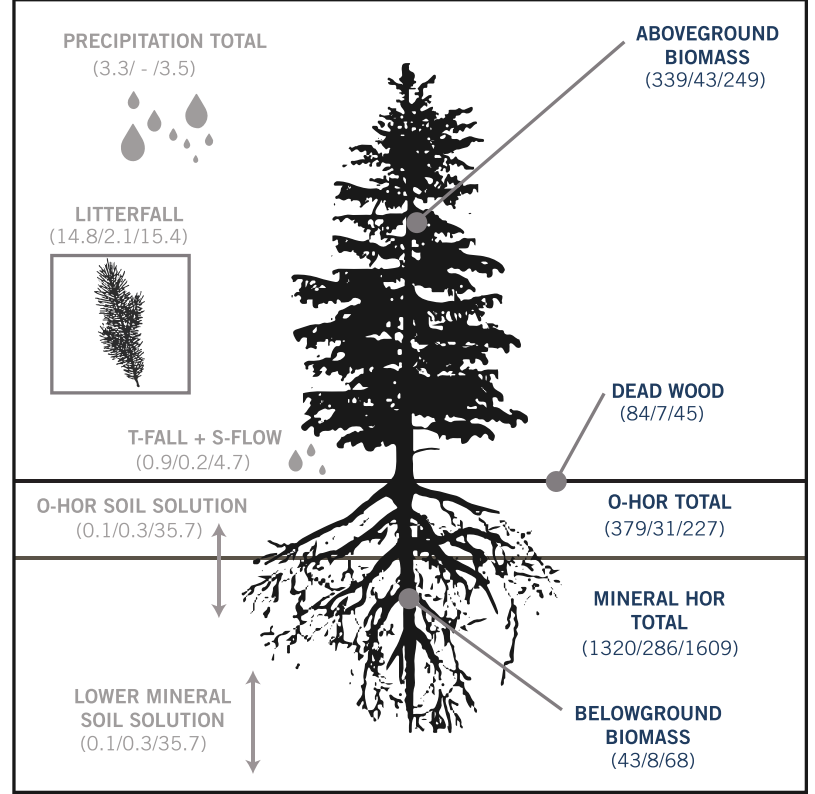

FLUX

POOLS

\section{DOUGLAS FIR SITE}

(PACIFIC NORTHWEST)

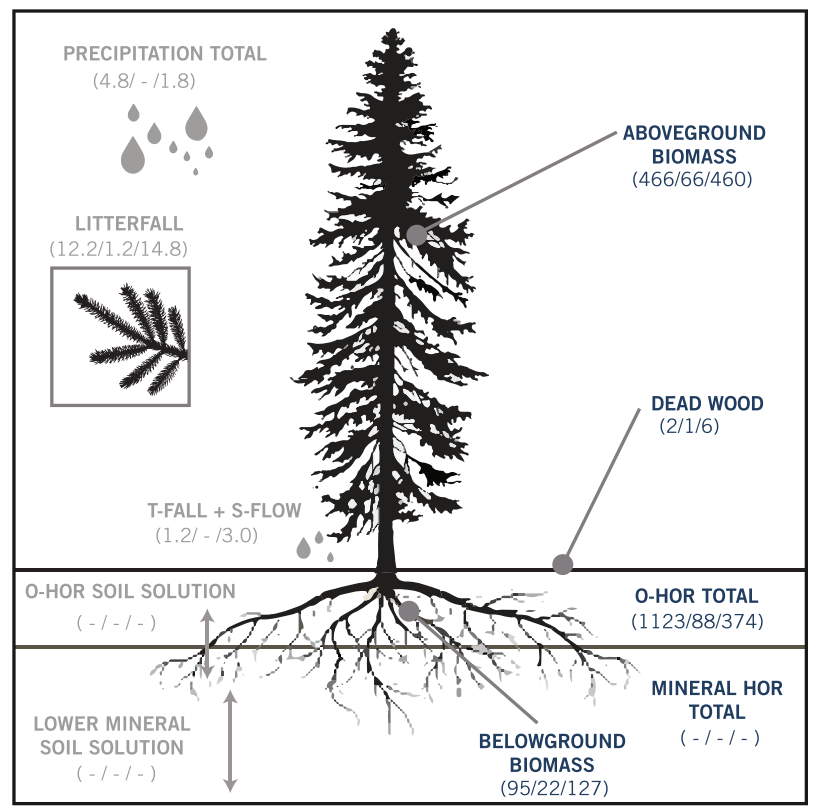

FLUX POOLS

NORTHERN NEW ENGLAND RED SPRUCE SITE

(BEAR BROOK, ME)
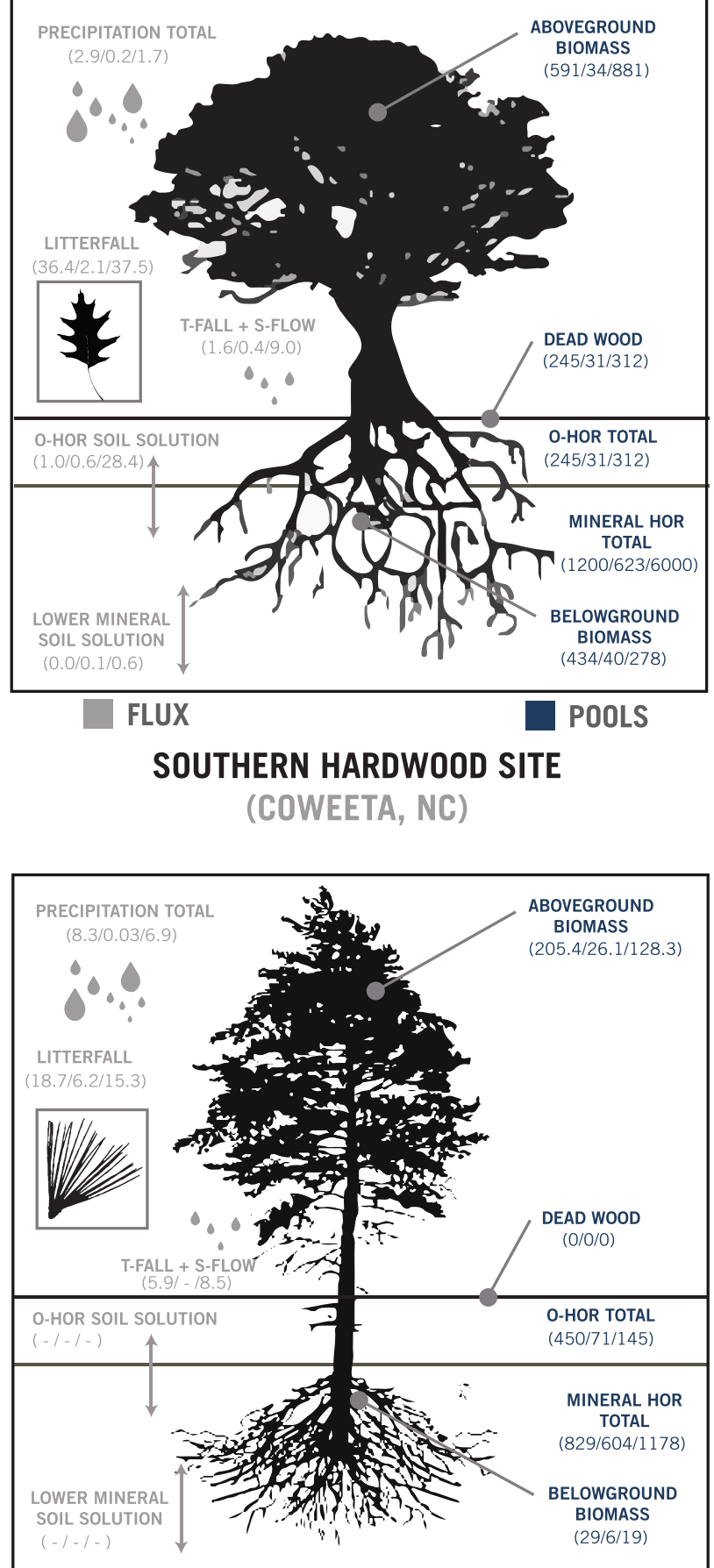

FLUX

POOLS

\section{SOUTHERN LOBLOLLY PINE SITE}

(DUKE, NC)

Fig. 4.1 Element pools and cycling of nitrogen $(\mathrm{N})$, phosphorus $(\mathrm{P})$, and calcium $(\mathrm{Ca})$ in representative forest ecosystems in the United States. Values are given as N/P/Ca and are expressed as $\mathrm{kg} \mathrm{ha}^{-1}$ for flux and $\mathrm{kg} \mathrm{ha}^{-1}$ for pools (source: Johnson and Lindberg 1992) 


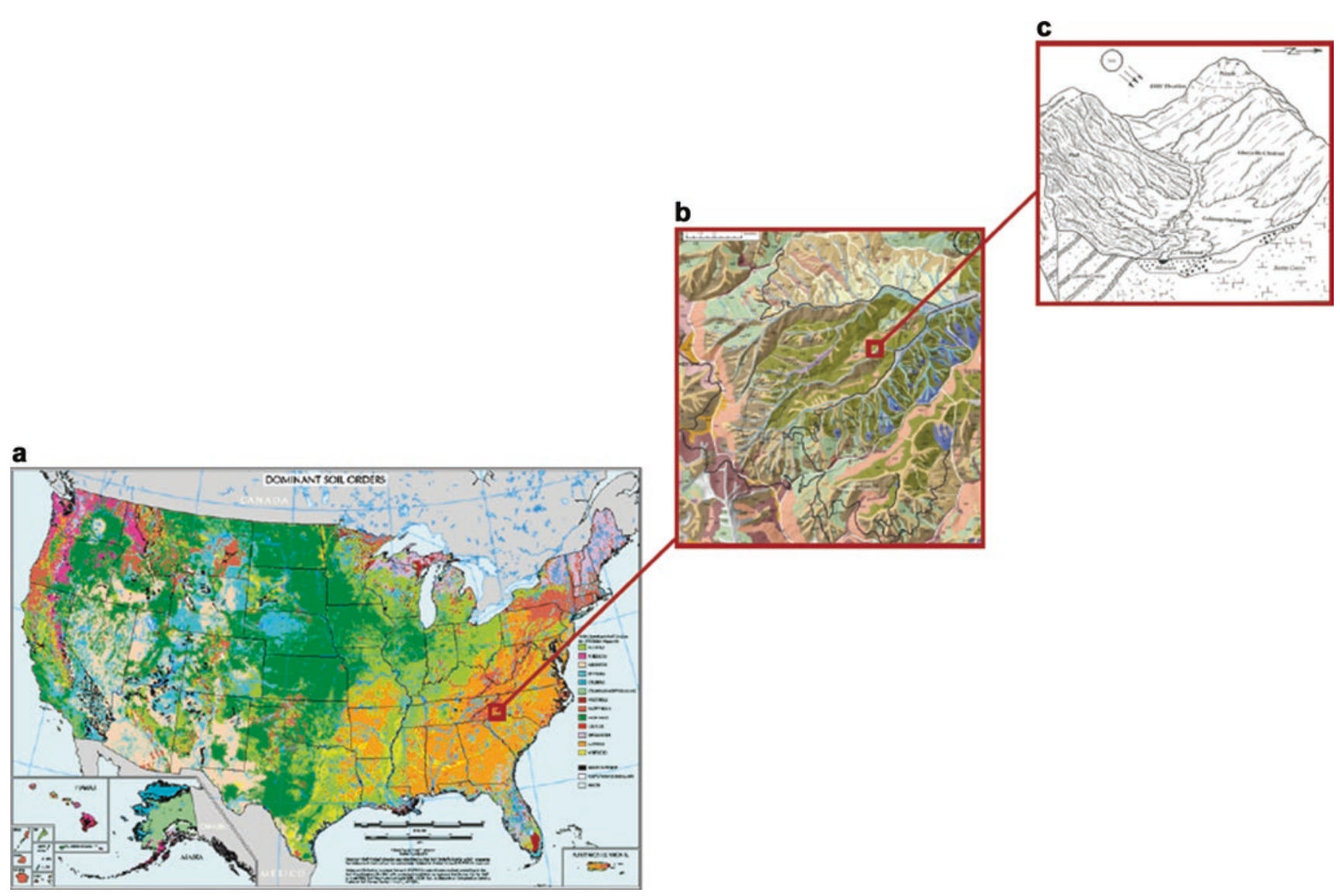

Fig. 4.2 Soils show high spatial variability across (a) soil orders at the continental scale, (b) soil series at regional scales, and (c) drainage classes at local hillslope scales

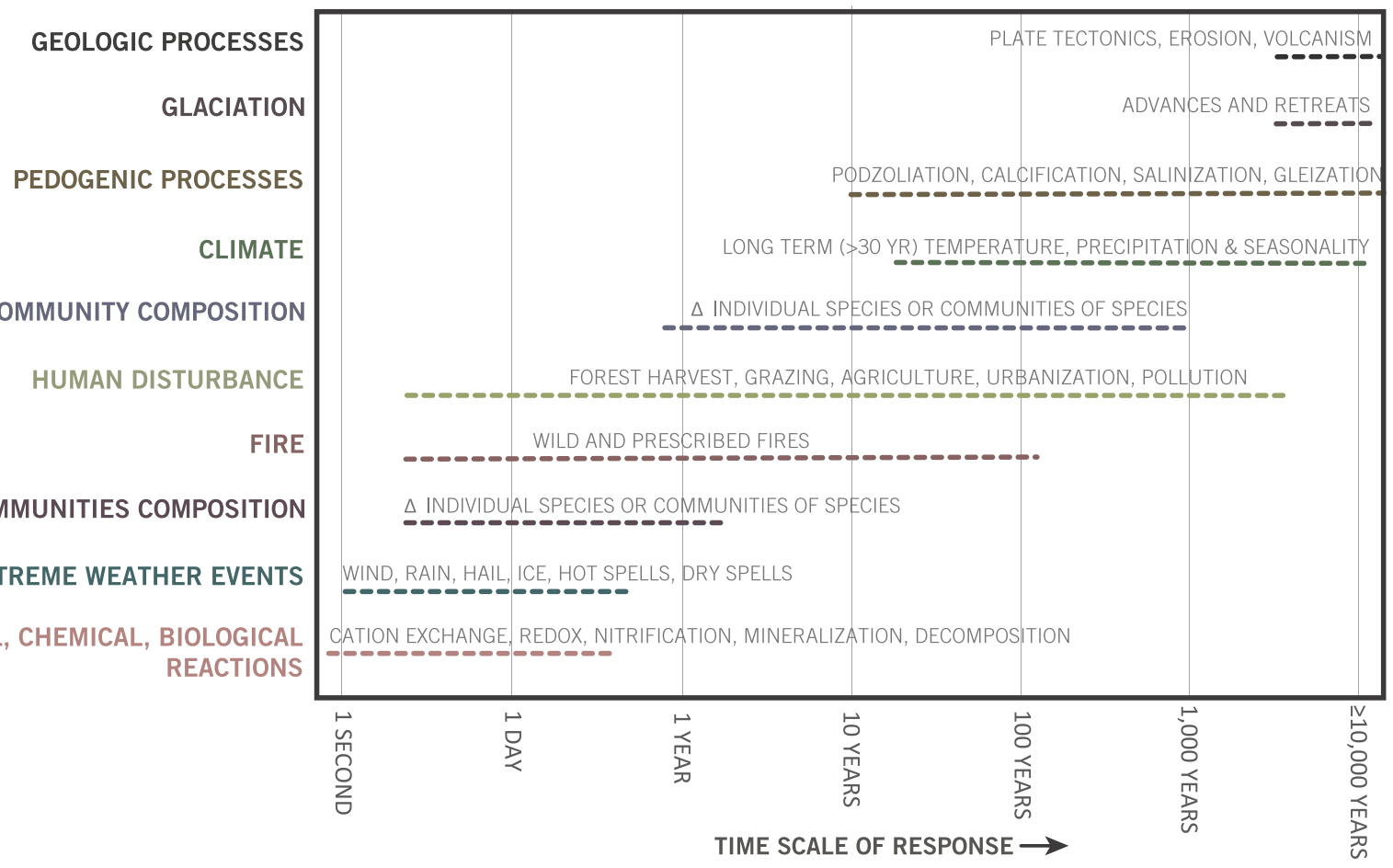

Fig. 4.3 Examples of timescale response for major drivers of soil change 
many of these studies in a comprehensive meta-analysis, which shows that traditional bolewood harvesting reduces soil organic $\mathrm{C}$ by an average of $8 \%$, with most of this reduction occurring in the organic horizons. Removing even greater quantities of biomass for bioenergy products was shown to have relatively little added effect (Johnson and Curtis 2001; Nave et al. 2010). In contrast, traditional forest harvests in which wood residues are left on site have been shown to increase soil organic C (Johnson and Curtis 2001). In addition, site preparation for plantation forestry, which often involves physical soil manipulations such as bedding, tillage, or ripping, can also reduce soil organic C (Nave et al. 2010).

In addition to the effects of biomass removals and redistributions on $\mathrm{N}$, harvesting is known to increase rates of soil nitrification and mineralization in some cases (Likens 1989). When coupled with reduced plant uptake due to aboveground biomass removal and belowground root disturbance, these effects can result in transient losses of $\mathrm{N}$ from soils to surface waters (and thus removal from the ecosystem) or to the atmosphere as a gas (Jerabkova et al. 2011; Likens 1989; Vitousek and Melillo 1979). Additional disturbance, such as site preparation, can magnify these processes (Burger and Pritchett 1984). This loss of $\mathrm{N}$ to surface waters following harvesting is well demonstrated at Coweeta Hydrologic Laboratory in North Carolina. Research conducted at this site showed that intensive forest management, such as plantation establishment (Adams et al. 2014) and clear-cutting, followed by site preparation (Webster et al. 2016) shifts forest $\mathrm{N}$ cycling and stream $\mathrm{N}$ export from a biologically controlled process in undisturbed reference streams to a hydrologically controlled process in highly disturbed watersheds. This overall "regime shift," which persists to this day, is also accompanied by a shift in seasonal patterns of $\mathrm{N}$ export. Reference stream $\mathrm{N}$ export is greatest in the summer, when soil $\mathrm{N}$ transformation rates are greatest, and least during the fall, when the addition of litter fall immobilizes $\mathrm{N}$; the disturbed watersheds only show a decline in $\mathrm{N}$ export in the fall.

Differences in the retention of $\mathrm{N}$ following forest harvest is a function of differences in $\mathrm{N}$ pool capacity (i.e., sinks in soils and vegetation) and kinetics of $\mathrm{N}$ processing (plant uptake and soil sorption) (Lovett and Goodale 2011). For example, Adams and others (2014) compared long-term stream data from watersheds with similar management in the Central (Fernow Experimental Forest in West Virginia) and Southern (Coweeta Hydrologic Laboratory in North Carolina) Appalachian Mountains. In both locations, reference watersheds retained more than $95 \%$ of incoming inorganic $\mathrm{N}$ deposition, and experimental clear-cutting shifted watersheds from net $\mathrm{N}$ retention to net loss. The net $\mathrm{N}$ loss at the Fernow Experimental Forest, however, was equal to approximately $150 \%$ of input compared to a net loss of only about $20 \%$ at the Coweeta Hydrologic Laboratory, reflecting the different pools and processes at these two sites (Box 4.1).
The connection between forest harvest and potential nutrient losses of soil base cations and $\mathrm{P}$, and consequent reductions in productivity for subsequent rotations, has caused concerns in parts of the United States where these nutrients are most limiting. For base cations, many studies have documented short-term and longer-term losses of base cations after the removal of biomass by harvest or by leach-

\section{Box 4.1}

Watershed (WS) response to experimental clear-cut logging (L) and conversion to conifers (C) compared to a reference $(\mathrm{R})$ in Coweeta Hydrologic Laboratory in North Carolina and the Fernow Experimental Forest in West Virginia shows how forest management impacts stream nitrogen (Box Fig. 4.1). Additional research at Coweeta indicates a regime shift in the seasonal patterns of $\mathrm{N}$ concentrations over time (Box Fig. 4.2), and data shows the relationship that exists between $\mathrm{N}$ export and stream discharge following experimental clear-cutting (Box Fig. 4.3).

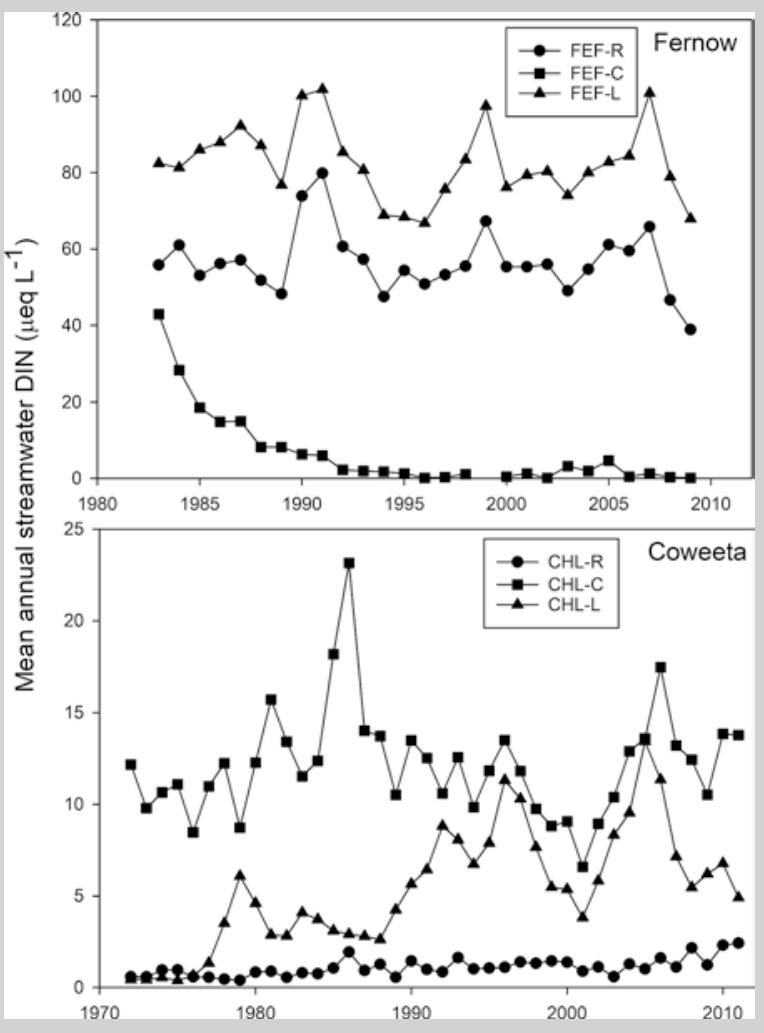

Box Fig. 4.1 Mean annual dissolved inorganic N (DIN) concentration in streams drining the six watershed at the Fernow Experimental Forest (top panel) and Coweeta Hydrologic Laboratory (bottom panel). For DIN, 1 ueg $\mathrm{L}^{-1}$ is $1 \mathrm{umol} \mathrm{L}^{-1}$. (Source Adams 2014, reprinted with permission) 


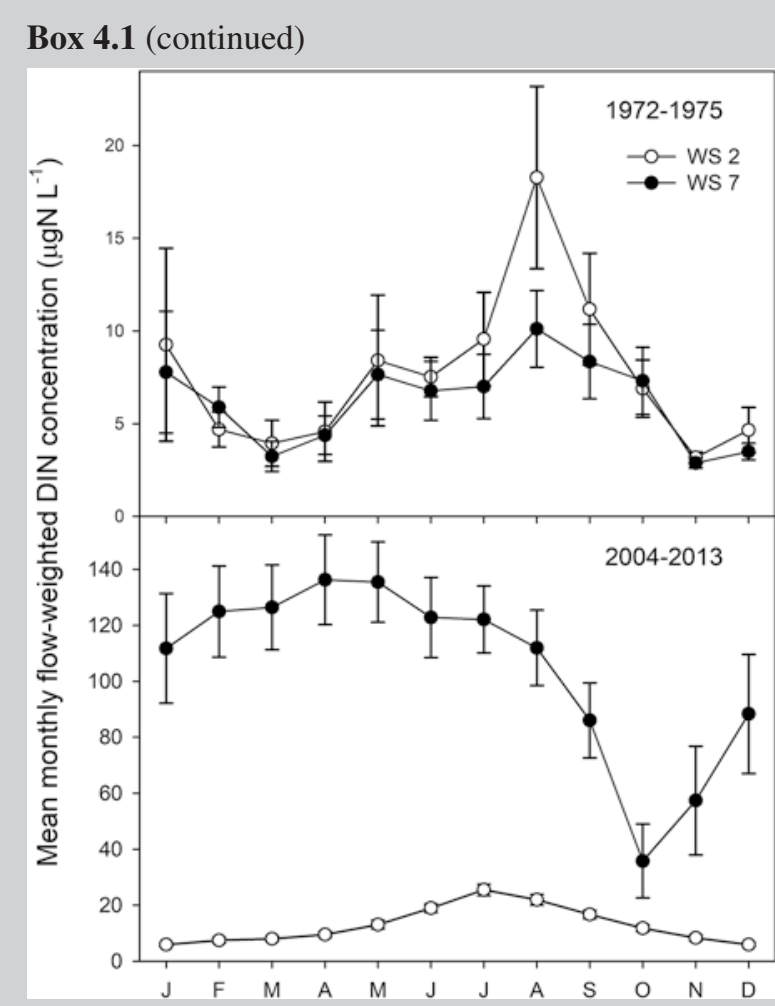

Box Fig. 4.2 Average (+/- SE) flow-weighted monthly dissolove inorganic nitrogen (DIN) concentrations for WS2 and WS7 before clearcutting (1972-1975, top panel) and for the most recent 10 years (2004-2013, bottom panel). In the bottom panel most error bars for WS2 are smaller than the symbols

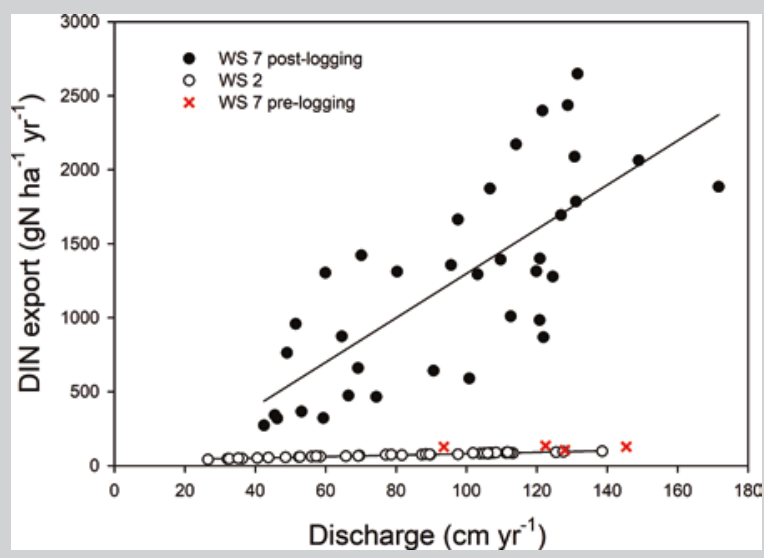

Box Fig. 4.3 Relationship between nitrogen $(\mathrm{N})$ export and stream discharge following clearcutting

ing losses (Federer et al. 1989; Hornbeck et al. 1990; Mann et al. 1988). For example, at the Hubbard Brook Experimental Forest in New Hampshire, commercial whole-tree and stripcut harvests resulted in a 4.8 and 1.9 times, respectively, greater stream export of $\mathrm{Ca}^{2+}$ over the first 8 years following cutting in the harvested watersheds compared to the undisturbed reference watershed (Likens et al. 1998). Longer-term studies found continued elevated $\mathrm{Ca}^{2+}$ export in streams draining the cut watersheds compared to the controls even after 32 years (Bailey et al. 2003). In another long-term study, Johnson and others (2016) reviewed base cation response for over 30 years following stem-only and wholetree harvest in a mixed oak (Quercus spp.) forest in Tennessee; they found that base cations were reduced in proportion to the amounts removed in harvest.

In the glaciated portion of the northeastern United States, potential base cation losses due to forest harvest, compounded by observed losses due to acidic precipitation, have caused concerns that soils of this region are becoming depleted of base cations, a condition referred to as "soil base cation depletion" (Adams et al. 2000; Federer et al. 1989; Huntington 2000). Soil base cation depletion has been documented by a variety of approaches, including repeated soil sampling (Bailey et al. 2005), mass balance models (Likens et al. 1996), and watershed scale acidification experiments (Fernandez et al. 2003). Soil base cation depletion, particularly $\mathrm{Ca}^{2+}$ depletion, has been implicated in regional forest declines, including sugar maple (Acer saccharum) decline (Horsley et al. 2002) and winter injury in red spruce (Picea rubens) (DeHayes et al. 1999). More research is needed to measure and model how base cations, input through the weathering of soil minerals or atmospheric deposition of dust, can replenish soil base cation stocks following harvest or during recovery from acid rain inputs (Yanai et al. 2005).

Phosphorus is a critical nutrient for tree growth and is often a limiting or colimiting nutrient in production forestry, particularly at sites on older, more highly weathered soils (Fox et al. 2007; Vitousek and Farrington 1997; Vitousek et al. 2010). Harvest-induced reductions in biologically available forms of soil organic $\mathrm{P}$ have been shown to reduce productivity at some sites, especially sites where P is already limiting (Scott and Dean 2006). Other studies have shown that forests may have strong internal controls on P loss. For example, Yanai (1998) reported that increases in $\mathrm{P}$ in surface water, following a wholetree harvest at the Hubbard Brook Experimental Forest, reduced rates of soil P mineralization due to feedbacks with phosphatase production and microbial immobilization, thereby reducing overall $\mathrm{P}$ losses from the system.

\section{Change in Species Composition}

Forest and rangeland management practices that alter plant species composition by changing the distribution of existing species or by introducing new species may fundamentally alter nutrient cycling dynamics (Hooper and Vitousek 1998; Tilman et al. 1997). These altered dynamics can be attributed to differences in plant life histories, aboveground and belowground vegetative structure, phenology, chemical composition of plant tissues, photosynthetic 
pathways, $\mathrm{N}$ fixation properties, and mycorrhizal associations. An often cited example is the difference in nutrient cycling between evergreen gymnosperms and deciduous angiosperms. In a comprehensive meta-analysis, Augusto and others (2014) compared nutrient cycling under these two forest types and showed that across 200 species representing 100 genera, soil pH, foliar and litter nutrient concentrations, decomposition rates, and net $\mathrm{N}$ mineralization and nitrification were generally lower. They also found that accumulation of soil organic matter in soils, weathering of soil minerals, and interception of nutrients in precipitation were generally higher in ecosystems dominated by gymnosperms compared to angiosperms. Forest management practices that shift stands from one of these forest types to the other, or that introduce one or more of these species, can thus have profound impacts on aboveground and belowground nutrient cycling. However, it should be noted that differences between individual species within these forest types can be as great as between forest types. Augusto and others (2014), for example, found that larch (Larix) species had higher $\mathrm{pH}$ litter and faster $\mathrm{N}$ cycling than other coniferous species, Binkley and Valentine (1991) found that $\mathrm{N}$ cycling was faster under white pine (Pinus strobus) than under green ash (Fraxinus pennsylvanica) or Norway spruce (Picea abies), and Binkley and others (1986) found higher nitrate $\left(\mathrm{NO}_{3}{ }^{-}\right)$leaching under white pine compared to hardwoods. In more arid environments, both woody plant expansion into grasslands and the invasion of annual grasses into shrublands have been shown to alter soil $\mathrm{C}$ and nutrient cycling, largely due to differences in plant life form, phenology, and tissue chemistry (Gill and Burke 1999).

\section{Forest Fertilization}

The growth of most forests is limited by current supplies of one or more nutrients. The most common limiting nutrients include $\mathrm{N}$ and $\mathrm{P}$ (Tamm 1991; Vitousek et al. 2010), but the base cations $\mathrm{Ca}^{2+}, \mathrm{Mg}^{2+}$, and $\mathrm{K}^{+}$, or even micronutrients such as B, Mn, Zn, or Si, can be limiting as well (Heiberg et al. 1964; Rashid and Ryan 2004; Thiffault et al. 2011). Forest managers have long recognized the benefits of forest soil fertilization to remedy these limitations and boost forest productivity. Fox and others (2007), for example, demonstrated the value of fertilization in managing the extensive loblolly pine (Pinus taeda) plantations in the southeastern United States. Their research showed that over an 8-year period, (1) the addition of $112 \mathrm{~kg} \mathrm{~N} \mathrm{ha}^{-1}$ increased forest growth by about $7 \mathrm{~m}^{3} \mathrm{ha}^{-1}$ annually, (2) the addition of $56 \mathrm{~kg} \mathrm{P} \mathrm{ha}{ }^{-1}$ yielded virtually the same growth response, and (3) the addition of the same amount of both $\mathrm{N}$ and $\mathrm{P}$ almost tripled the growth response to $20 \mathrm{~m}^{3} \mathrm{ha}^{-1}$ annually.
Alvarez (2012) further demonstrated this point in a modeling study that showed that soil nutrients limit forest growth across large swaths of forest lands of the southeastern United States, leading to large regional differences in the growth of loblolly pine plantations (Fig. 4.4). If soil nutrient limitations were alleviated, forest growth could be increased by $10-15 \%$. Similar nutrient limitations to productivity have been reported elsewhere across the country. In the north central United States, for example, Reich and others (1997) showed that forest plantations with an annual soil $\mathrm{N}$ supply of $45 \mathrm{~kg} \mathrm{ha}^{-1}$ produced about $14 \mathrm{~m}^{3} \mathrm{ha}^{-1}$ of wood annually, compared with forest plantations with an annual soil $\mathrm{N}$ supply of $90 \mathrm{~kg} \mathrm{ha}^{-1}$, which produced well over $21 \mathrm{~m}^{3} \mathrm{ha}^{-1}$ year $^{-1}$.

\section{Prescribed Fire}

Prescribed fire is the intentional use of low to moderate intensity fire as a management tool for a variety of purposes, including restoring or maintaining natural fire ecosystems, increasing soil $\mathrm{pH}$ and available nutrients, promoting new plant growth, controlling certain pathogens, creating wildlife habitat, and reducing the risk or severity of future wildfires (Elliott et al. 1999; McCullough et al. 1998; Neary et al. 1999; Vose and Elliott 2016; Vose et al. 1999). Prescribed fires affect forest and rangeland nutrient cycling by altering the distribution of nutrients within biomass pools and altering the physical, chemical, and biological properties of soils (Certini 2005; Knoepp et al. 2004; Richter et al. 1982). Depending on the intensity of the prescribed fire, aboveground and O-horizon nutrients can be oxidized and lost to the atmosphere, converted to ash or charcoal, or remain in incompletely burned vegetation or detritus (Vose and Swank 1993; Vose et al. 1999). Subsequent cycling of these nutrients follows similar pathways (Bodí et al. 2014; Boerner 1982; Certini 2005; Giovannini et al. 1988). Knoepp and others (2005) summarized variability in the soil nutrient response with fire severity. They showed that while total soil $\mathrm{N}$ and organic matter decline with increasing fire severity, available soil $\mathrm{N}$ increases after burning and remains higher for the first year, before returning to preburning levels. This increase was evident in stream $\mathrm{N}$ export (Knoepp et al. 2004). High severity fires typically result in a significant loss of ecosystem $\mathrm{N}$ and soil organic matter (SOM) (Swank and Vose 1993). The loss of SOM, in turn, results in decreased cation exchange capacity, especially in surface soils in which a greater proportion of exchange capacity is attributed to organic matter, not clay minerals.

Ash and charcoal, the materials that remain after partial or near-complete combustion of organic matter, consist of mineral elements and charred organic components (Bodí et al. 
Fig. 4.4 3PG model simulations for forest productivity across the southeastern United States with and without nutrient limitation (from Alvarez 2012). (a) Current growth of loblolly pine plantations ranges from about 300 to $600 \mathrm{~m}^{3} \mathrm{ha}^{-1}$ of wood volume at age 25 . (b) If soil fertility did not limit growth, many locations would show much higher productivity. (c) Current limits on soil fertility reduce forest growth by about 60-90 $\mathrm{m}^{3} \mathrm{ha}^{-1}$, a reduction of 15-20\%. (Source: Graphs based on illustrative simulations using the $3 \mathrm{PG}$ model, provided by Jose Alvarez-Munoz)
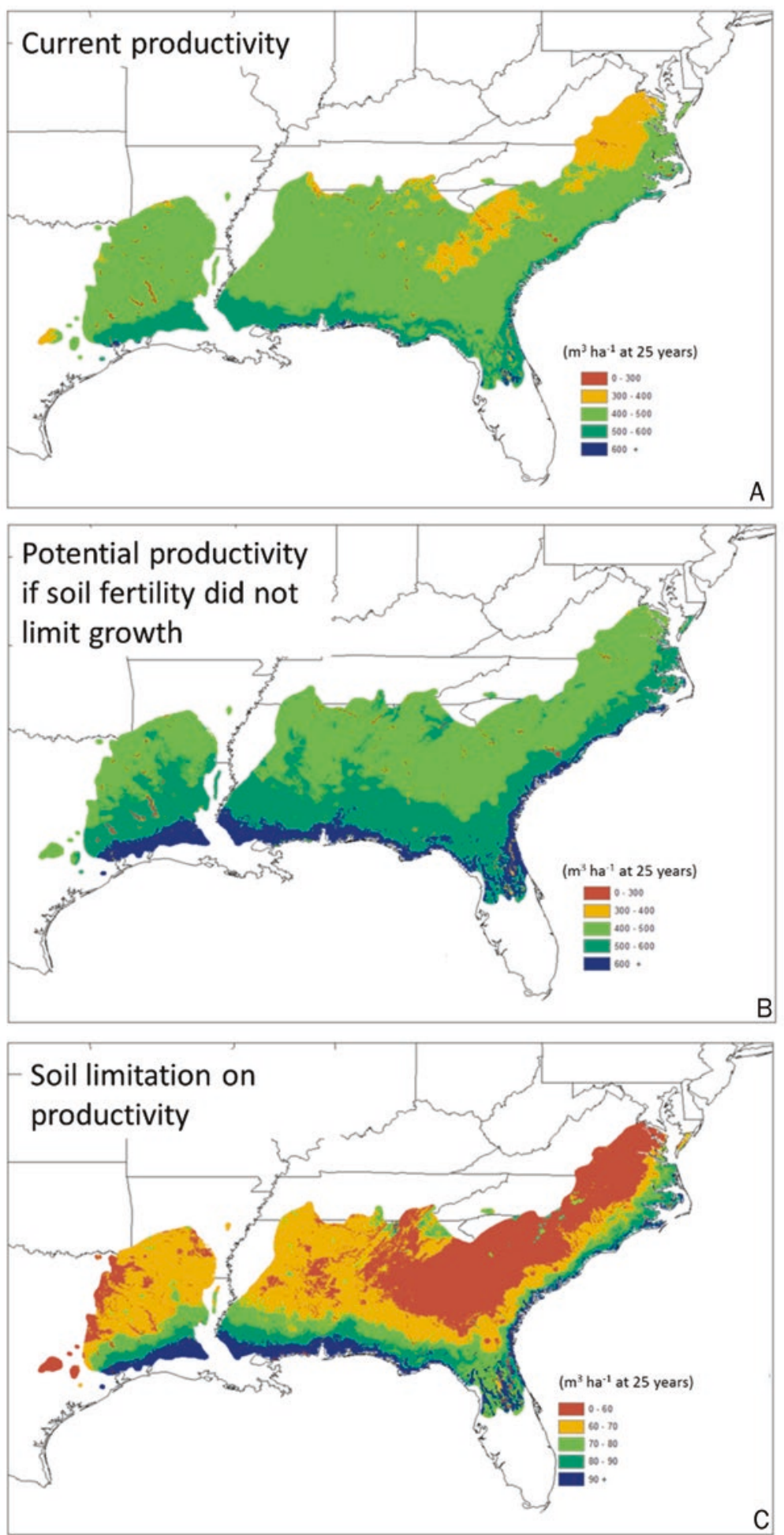

2014). The transformation of living biomass, fresh detritus, and especially SOM in the surface O-horizon to ash has direct and indirect effects on soil nutrient cycling. Base cations and small amounts of $\mathrm{P}, \mathrm{S}$, and $\mathrm{N}$ are released during organic matter combustion and can contribute to increased soil $\mathrm{pH}$ and plant nutrient availability. However, under con- ditions of severe burning, large layers of ash may remain on site. This material represents a range of pyrolysis compounds that tend to be resistant to chemical and biological degradation, thereby producing long-lasting effects on soil organic matter following fire (González-Pérez et al. 2004). 
Prescribed fire can also leave behind charcoal. Charcoal is not readily decomposed and can persist in the soil for many decades and may be effective in sequestering $\mathrm{C}$ in soils (Wardle et al. 2008) Additionally, charcoal can increase soil cation exchange capacity, nutrient availability, and $\mathrm{N}$ transformations (DeLuca et al. 2006) A review of the impacts of charcoal found widespread evidence for increased soil microbial biomass in addition to increased soil nutrients, including $\mathrm{K}, \mathrm{P}, \mathrm{N}$, and total $\mathrm{C}$. However, the addition of charcoal did not significantly impact plant productivity (Biederman and Harpole 2013).

\section{Environmental Pollutants}

Environmental pollutants include an array of point and nonpoint source contaminants that are introduced into the natural environment and cause adverse change. Pollutants that impact forest and rangeland nutrient cycles include atmospheric deposition of $\mathrm{S}, \mathrm{N}$, and mercury $(\mathrm{Hg})$; toxic and priority pollutants; and contaminants of emerging concern, such as pharmaceuticals and healthcare products.

\section{Atmospheric Deposition of Sulfur, Nitrogen, and Mercury}

\section{A Short History of Regulation and Research}

Anthropogenic emissions of sulfur dioxide $\left(\mathrm{SO}_{2}\right)$ and nitrogen oxides $\left(\mathrm{NO}_{\mathrm{x}}\right)$ began with the Industrial Revolution around the late 1700s. These pollutants mix with water in the atmosphere and form the acidic compounds sulfuric $\left(\mathrm{H}_{2} \mathrm{SO}_{4}\right)$ and nitric $\left(\mathrm{HNO}_{3}\right)$ acids, which are returned to the Earth at potentially long distances from their source in what is generally known as atmospheric deposition or, colloquially, "acid rain." The impacts of atmospheric deposition on forested ecosystems as a subject of research began in the midtwentieth century in Europe (Odén 1968), the northeastern United States (Likens and Bormann 1974; Likens et al. 1972). By the early 1980s, national programs were implemented to study the effects of atmospheric deposition on ecosystems and to examine the impacts of deposition on vegetation, soils, and water. The result was a series of major studies, including the Integrated Forest Study (IFS), an international effort with 15 sites in the United States and 1 each in Canada and Sweden, designed to understand the impacts of atmospheric deposition on forested ecosystems (EPRI 1972), and the National Acid Precipitation Assessment Program (NAPAP 1980). The final output of the IFS was the publication of a synthesis document and the development of the Nutrient Cycling Model known as NuCM (Johnson and Lindberg 1992; Liu et al. 1991), which utilizes detailed vegetation, soil, and water data to predict ecosystem responses to deposition scenarios and to increases, decreases, and changes in atmospheric chemistry. These comprehensive research programs contributed the scientific underpinnings for the passage of the Clean Air Act Amendment (1990) and additional emission regulations, which have resulted in significant declines in industrial $\mathrm{SO}_{2}$ and $\mathrm{NO}_{\mathrm{x}}$ emissions and $\mathrm{H}_{2} \mathrm{SO}_{4}$ and $\mathrm{HNO}_{3}$ concentrations in rainfall (Fig. 4.5). The US Environmental Protection Agency (US EPA) reported that by 2011, S deposition across the United States had decreased by over 50\% (US EPA 2015) (Fig. 4.5). The IFS ecosystem-level measurements and research efforts continue in many locations (e.g., USDA Forest Service Experimental Forests and Rangelands and National Science Foundation Long Term Ecological Research sites) and are now focusing on recovery processes that are occurring due to deposition reductions that resulted from the successful implementation of national and regional air quality improvement efforts. The story of acid rain, including the identification of the problem, the history of scientific research, the communication of this research to stakeholders and policymakers, the implementation of pollution controls, and the resulting decline in emissions and recovery of ecosystems, is a model for the successful integration of research, management, and policymaking.

Mercury, which comes from both anthropogenic and natural sources, is another atmospheric pollutant of concern. An estimated $48 \%$ of atmospheric $\mathrm{Hg}$ emitted in 2015 was from coal- and oil-fired power plants (US EPA 2018). As with S and $\mathrm{N}$, industrial $\mathrm{Hg}$ emissions began increasing in the $1800 \mathrm{~s}$ (Swain et al. 1992; Yin et al. 2010). However, as a result of clean air legislation, shifts from coal to other fuel sources, and use of new technology, $\mathrm{Hg}$ emissions declined by nearly $50 \%$ between 2005 and 2015 (Fig. 4.5). Mercury has known deleterious biotic effects and is of particular concern to human health. While the original Clean Air Act and its Amendments did not include $\mathrm{Hg}$ standards, the US EPA finalized $\mathrm{Hg}$ emissions regulations in February 2015 and completed reporting protocols in April 2017 that went into effect in June 2018.

\section{Impacts of Atmospheric Sulfur, Nitrogen, and Mercury Deposition on Forest and Rangeland Biogeochemical Cycling}

Research on the effects of atmospheric deposition has focused on plant, microbial, soil, and surface water processes. Both $\mathrm{N}$ and $\mathrm{S}$ are essential nutrients and are taken up by plants and microbes. This uptake is mediated by seasonal patterns of plant and microbial growth driven by changes in temperature and water availability. Ecosystem $\mathrm{N}$ uptake is dominated by biological processes. In some forests, added atmospheric $\mathrm{N}$ can have a fertilizing effect; in others, especially where $\mathrm{N}$ deposition is high, the added atmospheric $\mathrm{N}$ can exceed the capacity of the forest to take up the added N. This can result in N saturation (Aber et al. 1989, 1998), 


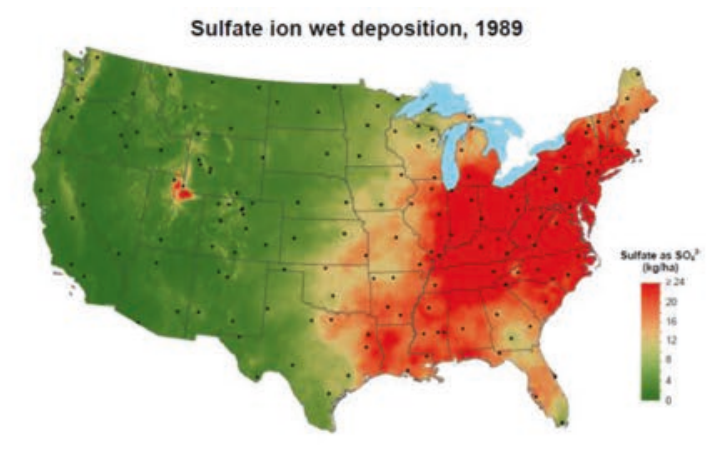

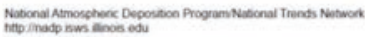

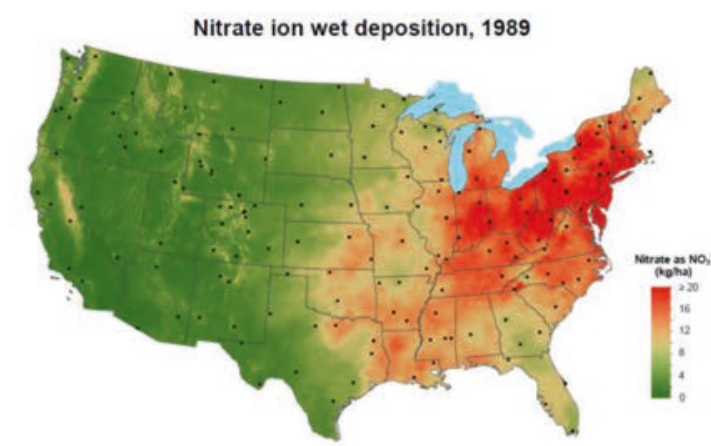

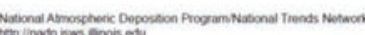

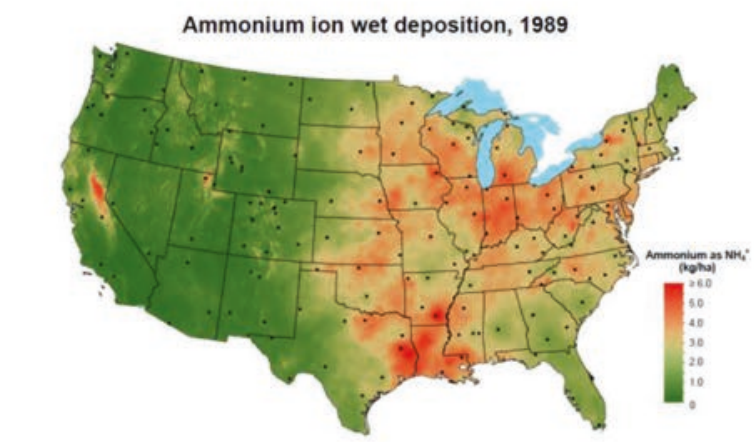

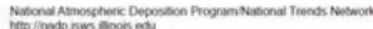

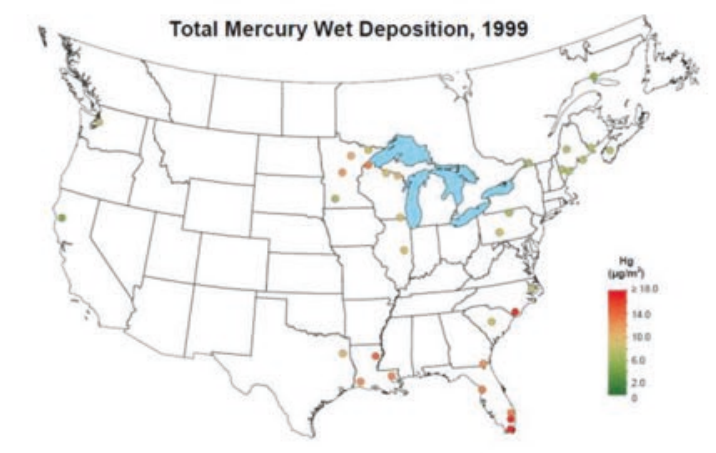

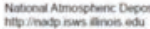

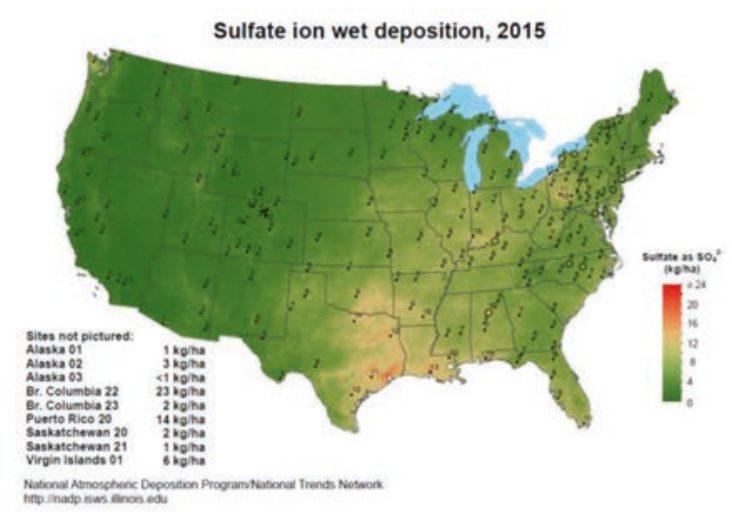

Nitrate ion wet deposition, 2015
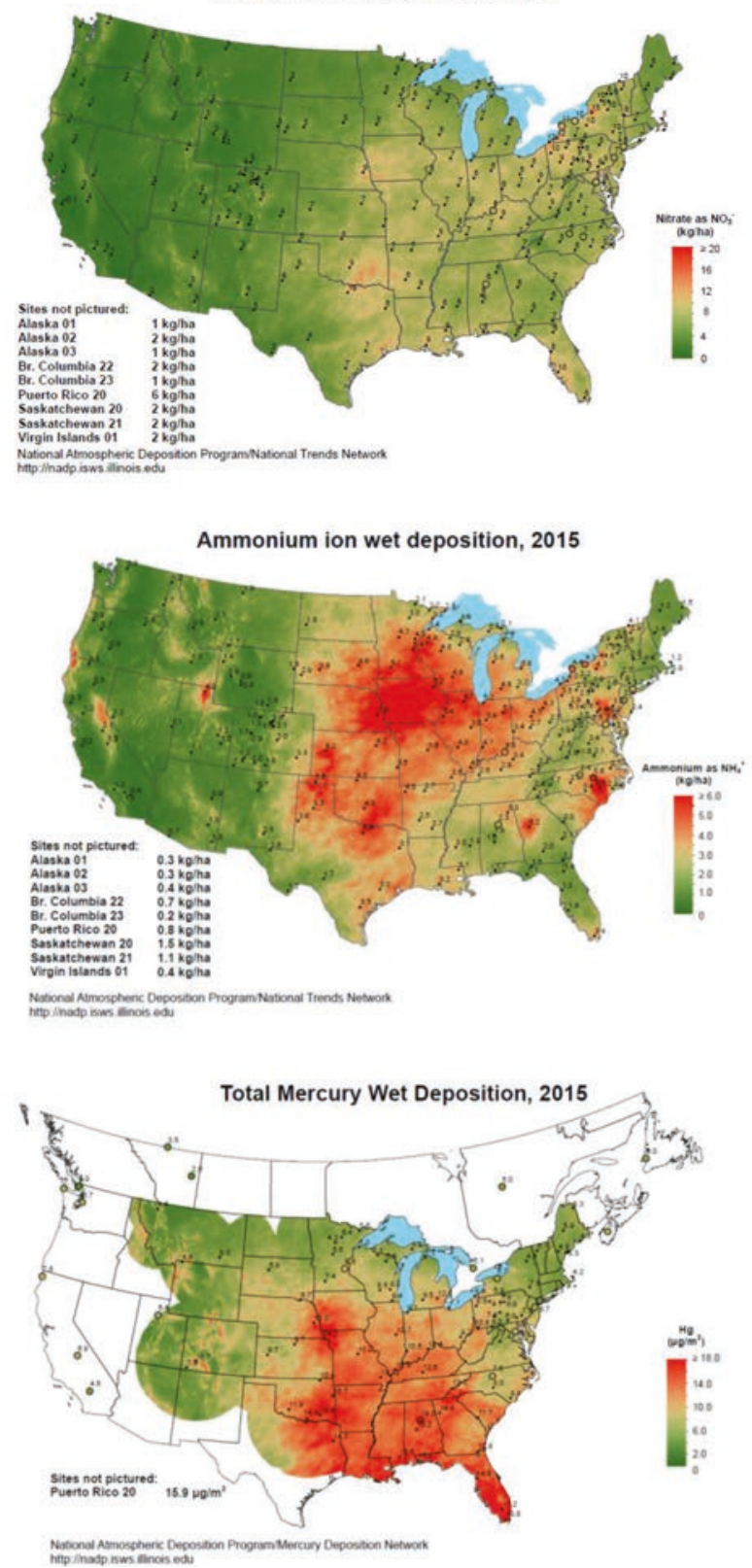

Fig. 4.5 Total wet deposition of sulfate, nitrate, and ammonium ions and mercury in 1999 and 2015. (Source: US EPA 2015) 
where excess $\mathrm{N}$ appears, sometime deleteriously, in soil and surface waters. Ecosystem S cycling, in contrast, is dominated by chemical and physical processes (Johnson 1984; Swank et al. 1984). Sulfate anions (and to a lesser extent $\mathrm{NO}_{3}^{-}$anions) are retained within soil by $\mathrm{pH}$-dependent, variable-charge reactions with soil clay particles and organic matter (Strahm and Harrison 2007). The strength and capacity for these reactions is dependent on the soil mineralogy and organic matter chemistry with a sorption affinity for $\mathrm{SO}_{4}{ }^{2-}$ that is greater than $\mathrm{NO}_{3}{ }^{-}$. Inputs of atmospheric $\mathrm{SO}_{4}{ }^{2-}$ (and $\mathrm{NO}_{3}{ }^{-}$) anions that exceed the soils capacity for retention can result in the removal of soil base cations such as $\mathrm{Ca}^{2+}$ (Bailey et al. 2005; Johnson 1984) and potentially mobilize aluminum $\left(\mathrm{Al}^{3+}\right)$ (Lawrence et al. 2007), which can negatively impact plant roots (Shortle and Smith 1988) as well as surface water quality and aquatic flora and fauna (Lawrence et al. 2007).

In contrast to $\mathrm{N}$ and $\mathrm{S}, \mathrm{Hg}$ is not a nutrient, and it can be highly toxic to terrestrial and aquatic organisms, particularly as it accumulates and becomes concentrated in the food chain in the form of methylmercury (Giller et al. 1998; Matida et al. 1971; Patra and Sharma 2000). This toxicity to plants and microorganisms in the soil will directly or indirectly alter soil biogeochemical cycles. Mercury can be taken up in gaseous form by plants, or it can be deposited as particles on vegetation surfaces; in both cases, $\mathrm{Hg}$ reaches the soil in litterfall (Jiskra et al. 2015). A portion of the deposited $\mathrm{Hg}$ can quickly revolatilize (Frossard et al. 2017). As the litter in the $\mathrm{O}$ horizon decomposes, $\mathrm{Hg}$ is incorporated into the soil organic matter and ultimately moves into the mineral soil where a large proportion is retained (Allan and Heyes 1998). Formation of methylmercury compounds occurs through the reduction of organically bound $\mathrm{Hg}$ by soil microbial activity. Methylmercury has a particular affinity for sulfhydryl compounds, which increases its toxicity. Under saturated conditions, methylmercury can be re-emitted to the atmosphere. Emissions of $\mathrm{Hg}$ from soil surfaces increase following disturbance from forest harvesting (Carpi et al. 2014; Mazur et al. 2014) or burning (Carpi et al. 2014). Although our understanding of the inputs and cycling of $\mathrm{Hg}$ through the air-plant-soil continuums is improving, more research is needed on the impacts of this toxic pollutant on the biogeochemical cycling of other elements in forest and rangeland ecosystems. See Chap. 6 for more details about $\mathrm{Hg}$ in wetlands.

\section{Ecosystem Response to Declining Atmospheric Pollutants of Sulfur, Nitrogen, and Mercury}

Implementation of clean air legislation, shifts to cleaner fuel sources, and use of new technology have resulted in declining emissions of the atmospheric pollutants $\mathrm{S}, \mathrm{N}$, and $\mathrm{Hg}$. Studies have linked declining industrial $\mathrm{S}$ emissions to declining atmospheric inputs of $\mathrm{SO}_{4}{ }^{2-}$, increases in surface water $\mathrm{pH}$ and base cations (largely $\mathrm{Ca}^{2+}$ ), and declines in stream water $\mathrm{Al}^{3+}$ (Lawrence et al. 2012) and $\mathrm{SO}_{4}{ }^{2-}$ concentrations (Kahl et al. 2004; Likens et al. 2002; Rice et al. 2014). Despite these signs of "recovery" in response to reduced $\mathrm{SO}_{4}{ }^{2-}$ inputs, many studies also report lags in recovery processes. These lags in recovery have been largely attributed to $\mathrm{SO}_{4}{ }^{2-}$ that had been adsorbed onto soil exchange sites or stored in soil organic matter that is released back into soil and surface waters (Mitchell and Likens 2011). The shift from soil $\mathrm{SO}_{4}{ }^{2-}$ retention that occurred under high $\mathrm{SO}_{4}{ }^{2-}$ deposition scenarios to the release of soil $\mathrm{SO}_{4}{ }^{2-}$ under lower deposition scenarios is predicted to occur over the next two decades in unglaciated soils of the eastern United States, with the dates advancing from North to South (Rice et al. 2014). Lags in recovery have been reported for soil and stream acidity because the base cations $(\mathrm{Ca}, \mathrm{Mg}, \mathrm{K}$, and $\mathrm{Na}$ ), which neutralize acidity and were removed from soils by decades of acidification, are only slowly replenished through atmospheric inputs and mineral weathering processes. To better understand the soil processes involved in ecosystem recovery from acidic deposition and to improve the temporal estimates of the recovery process (Lawrence et al. 2015), more research is needed that focuses on long-term soil resampling efforts, using previously sampled sites with archived soil samples.

Nitrogen dynamics present a different set of research challenges. Nitrate deposition across the continental United States is declining, while ammonium $\left(\mathrm{NH}_{4}^{+}\right)$deposition is increasing (Li et al. 2016) (Fig. 4.5). Although both forms of $\mathrm{N}$ are taken up by the biota, the principles of chemical neutrality require that the uptake of $\mathrm{NO}_{3}{ }^{-}$is accompanied by the release of a negatively charged ion, typically an organic compound, whereas the uptake of $\mathrm{NH}_{4}{ }^{+}$is accompanied by the release of a hydrogen ion $\left(\mathrm{H}^{+}\right)$, an acidifying element. The impacts of the change in the dominant form of atmospheric $\mathrm{N}$ deposition on forest and rangeland biogeochemical cycling is currently under investigation.

Compounding the uncertainties about recovery from atmospheric $\mathrm{N}$ deposition is the observation that nutrient pools and processes change over time due to changes in species composition, $\mathrm{N}$ saturation, climate, or other factors. Argerich and others (2013), for example, examined changes in stream $\mathrm{NO}_{3}{ }^{-}$concentrations at Forest Service experimental forests across the continental United States and found different patterns of long-term change. Stream $\mathrm{NO}_{3}{ }^{-}$concentrations increased over time at Coweeta Hydrologic Laboratory and Fernow Experimental Forest; declined at Hubbard Brook Experimental Forest, H.J. Andrews Experimental Forest in Oregon, and Luquillo Experimental Forest in Puerto Rico; and did not change at Marcel Experimental Forest 
in Minnesota. These patterns of change vary depending on the length of record and may be due, in part, to shifts from $\mathrm{NO}_{3}{ }^{-}$to $\mathrm{NH}_{4}{ }^{+}$deposition or changes in forest productivity. Additional research is needed to address this issue.

The body of work on the response of forest soils to increases and decreases in atmospheric mercury deposition is sparse. For more information on this topic, see Chap. 6.

\section{Critical Loads of Atmospheric Sulfur and Nitrogen}

The concept of critical loads has been used extensively in Europe and more recently in the United States to help inform air pollutant control policies (Nilsson 1988; Pardo et al. 2011). A critical load has been defined as "the quantitative exposure to one or more pollutants below which significant harmful effects on sensitive elements of the environment do not occur, according to present knowledge" (Nilsson and Grennfelt 1988). Exceedances of critical loads of atmospheric inputs of $\mathrm{SO}_{4}{ }^{2-}$ and $\mathrm{NO}_{3}{ }^{-}$can result in soil and surface water acidification, $\mathrm{N}$ saturation, and changes in biotic community composition and activity, resulting in shifts in biogeochemical cycling of a range of nutrients (Burns et al. 2008; Pardo et al. 2011). In a continental study, McNulty and others (2007) estimated that about $15 \%$ of forest soils in the conterminous United States were in exceedance of their critical acid load. These exceedances were most common in New England and West Virginia, with only rare occurrences in the western United States. Although critical loads are a useful tool for expressing chronic ecosystem vulnerability to acidic $\mathrm{S}$ and $\mathrm{N}$ inputs, additional research on mineral weathering rates and biologically relevant thresholds of response are needed to better constrain these short- and longer-term estimates.

The Clean Air Act and its Amendments have resulted in improved air quality and declining inputs of $\mathrm{SO}_{4}{ }^{2-}$ and $\mathrm{NO}_{3}{ }^{-}$, and current models predict that $\mathrm{SO}_{4}{ }^{2-}$ and $\mathrm{NO}_{3}{ }^{-}$deposition will soon be below soil critical load values for much of the country. However, the effect of increases in the atmospheric deposition of $\mathrm{NH}_{4}{ }^{+}$remains unknown and warrants further study.

\section{Toxic and Priority Pollutants}

The Clean Water Act and its Amendments identify 56 "toxic pollutants" and 126 "priority pollutants" that are now regulated as part of the US national standards for wastewater discharges to surface water (Copeland and Library of Congress, Congressional Research 1993). These pollutants are made up of a wide range of compounds including lead $(\mathrm{Pb}), \mathrm{Hg}$, organic chemicals, and pesticides that are commonly found in municipal and industrial effluent and for which there are approved analytical testing methods. These substances can enter soil systems and be incorporated into forest and rangeland nutrient cycles via diffuse pollution pathways including subsurface migration from treatment plants; stormwater from streets; spreading of waste materials or sludge on agricultural or forest lands; and runoff from agricultural, urban, exurban, and industrial sites. Many of these pollutants are directly toxic to trees and soil microorganisms and macroorganisms and thus directly or indirectly affect forest nutrient cycles. Although this is largely an issue for urban or suburban soils, the harmful impacts are likely to become more widespread with increased urbanization, industrialization, and fragmentation of forest and rangelands across the United States (see also Chap. 7).

\section{Contaminants of Emerging Concern}

In addition to the toxic and priority pollutants, novel classes of pollutants, collectively known as "contaminants of emerging concern" by the US EPA, are increasingly being released into the environment. These consist of a range of pharmaceuticals and personal care products (collectively called PPCPs) and endocrine-disrupting agents (Caliman and Gavrilescu 2009; Doerr-MacEwen and Haight 2006). Pharmaceuticals include a wide array of steroidal and nonsteroidal anti-inflammatory drugs, antidepressants, anticonvulsants, and antibacterial agents; personal care products that contain chemicals such as phthalates, parabens, and formaldehyde; endocrine-disrupting agents including diethylstilbestrol (the synthetic estrogen DES), dioxin, and dioxin-like compounds; and polychlorinated biphenyls (PCBs), DDT, and some other pesticides. These chemicals have been engineered for specific human and animal therapeutic and hygienic functions, but may cause adverse environmental toxicological effects in soils and surface waters, and thus impact biogeochemical cycles in these systems. These compounds are excreted or disposed of in home, farm, and municipal sewage systems, where they are either degraded or released into the environment in wastewater or sludge. They are now commonly detected near population and agricultural centers and are increasingly being detected in relatively remote environments (Kallenborn et al. 2017). Bernhardt and others (2017) caution that the rate of increase in the production and variety of pharmaceuticals and other synthetic chemicals over the past four decades outpaces the increase in other drivers of global change, including rising atmospheric carbon dioxide $\left(\mathrm{CO}_{2}\right)$ concentrations, nutrient pollution, habitat destruction, and biodiversity loss. More information is urgently needed on the unintended impacts of these substances on organisms, their biochemical degradation, persistence in the environment, and bioaccumulation in the food chain. The release of these substances into the environment is undoubtedly having an impact on forest and rangeland nutrient cycles, especially those near urban and suburban areas. Effects on nutrient cycles will likely continue into the future as urbanization increases and the race for new medications and healthcare products continues. 


\section{Climate Change, Climate Variability, and Extreme Weather Events}

The climate and weather of the United States are undergoing a period of rapid change, characterized by continental-scale increases in temperature; longer growing seasons; alterations in the amount, distribution, and intensity of precipitation; decreases in snow and ice cover; and an increase in the frequency and severity of extreme weather events (Box 4.2). Coupled atmosphere-ocean general circulation models suggest that this pat-

\section{Box 4.2 Climate Change in the United States}

The climate of the continental United States has changed over geologic, millennial, and decadal timescales:

\section{Climate Change over Geologic and Millennial Timescales}

On a geologic timescale, or during the Quaternary period from 2.58 million years ago to the present, North America has experienced a series of glacial and interglacial periods that have shaped the landscape, soils, and biota of the country. The last ice sheet, which covered much of the northeastern corner and northern tier of the contiguous United States, retreated approximately 11,700 years ago. Based on temperature reconstructions from ice cores, the estimated mean annual temperatures have fluctuated approximately $9{ }^{\circ} \mathrm{C}$ during these glacial-interglacial cycles. Roughly 6000 years ago, the Earth (especially the Northern Hemisphere) experienced a warmer period called variously the Mid-Holocene warm period, Hypsithermal, or the Climatic Optimum. This warmer period was characterized by temperatures as much as $4{ }^{\circ} \mathrm{C}$ warmer than present and was caused by changes in the Earth's orbit. Over the past millennium, the climate has fluctuated between the cooler period during the Little Ice Age, which lasted from about1300 to the mid-1800s, and the warming period characterizing the past 100 years. Estimated mean annual temperatures, based on a variety of direct measurements and temperature reconstructions from ice cores, pollen, and tree ring records (IPCC 2014), have fluctuated approximately $1.4{ }^{\circ} \mathrm{C}$ during the last 1000 years.

\section{Recent Climate Change}

Since approximately the end of the Little Ice Age, which coincided with the beginning of the Industrial Revolution, the global climate has changed more rapidly than at any time in the preceding 800,000 years (IPCC 2014). The overwhelming scientific consensus is that this rapid change is in large part due to increased anthropogenic emissions of heat-trapping greenhouse gases, including carbon dioxide, methane, and nitrous oxide (IPCC 2014), resulting from the burning of fossil fuels, cement production, and global shifts in land use, such as the loss of significant portions of the world's C-rich tropical forests. In the United States, the average annual air temperature has increased by an average of $0.6-1.1{ }^{\circ} \mathrm{C}$ for the period from 1895 to 2014 , with the greatest warming observed in the more northern states and the least across the Southeast. The average annual precipitation across the United States has increased by about $5 \%$ during this same period, with increased precipitation in the Northeast, Midwest, and southern Great Plains and decreased precipitation in the Southeast and Southwest. Other changes include an increase in the amount of rain falling in large events (especially in the Northeast), an increase in the length of the frost-free period, and a general intensification of the hydrologic cycle (Hayhoe et al. 2007; Huntington 2006; Melillo et al. 2014).

\section{Projected Future Climate Change}

Coupled atmosphere-ocean general circulation models predict more change to come, with the amount of change dependent on future greenhouse gas emissions (Melillo et al. 2014). Under a low emissions scenario, which assumes substantial reductions in emissions, mean annual temperatures in the United States are projected to increase by $1.7-2.8^{\circ} \mathrm{C}$; under a higher emissions scenario, the temperature increase could be as much as $2.8-$ $5.6{ }^{\circ} \mathrm{C}$, with the largest increases expected for the upper Midwest and Alaska. Projected future precipitation changes are multidirectional (i.e., some regions receive more precipitation; some receive less) and vary by region and season. The overall trend is for more precipitation and wetter future conditions in the North and less precipitation and dryer conditions in the South (Melillo et al. 2014). Summers are projected to be dryer in most areas of the continental United States, especially in the Northwest and South-Central region. The Southwest is projected to be particularly dry in the winter and spring, while Alaska is projected to be wetter in all seasons. 
tern of change will continue into the future (IPCC 2014; Melillo et al. 2014). These continental-scale changes in climate, together with an increasing frequency and severity of extreme weather events, have had and will continue to have direct and cascading indirect impacts on the distribution of terrestrial ecosystems across the country, the productivity of these ecosystems, and the rates of internal physical, chemical, and biological processes, all of which affect nutrient cycling dynamics.

\section{Temperature and Precipitation as Major Factors of Biome Distribution}

Temperature and precipitation have long been recognized as major dynamic factors that determine the distribution of terrestrial biomes across the landscape, with desert biomes occupying the hottest and driest regions, temperate forests and grasslands occupying regions characterized by moderate temperatures and rainfall, and tropical rainforest occupying the hottest and wettest regions (Holdridge 1947; Whittaker 1975). Temperature and precipitation also influence the change in biomes with elevation, including the often sharp delineation between boreal forests and alpine tundra that characterizes the tree line. Across the United States, the observed and projected changes in climate are expected to result in the northward expansion of the deserts of the Southwest, the Mediterranean shrublands of the West Coast, the subtropical forests of the Southeast, and the temperate and boreal forests and grasslands of the central and northern United States. Shrub encroachment on arid and semiarid grasslands (D'Odorico et al. 2010; Knapp et al. 2008), invasion of the tundra ecosystems of Alaska by shrubs and trees (Suarez et al. 1999), and the retraction of broad expanses of permafrost soils (Camill 2005; Payette et al. 2004) have already been documented. Increasing temperature may also move biome ecotones upward in elevation (Parmesan and Yohe 2003; Walther 2003). The increasing frequency of extreme weather events, such as hurricanes, droughts, floods, and ice storms, will also cause extensive damage leading to the exceedance of local ecological or physiological thresholds, resulting in transient to permanent state changes, such as conversions of forests to shrublands or shrublands to grasslands (Smith 2011). Because different biomes, as well as different assemblages of species within a biome, are characterized by different intrinsic rates of nutrient cycling, major or even subtle climate shifts or extreme weather-driven shifts in the distribution of these biomes or species assemblages will impact landscape-scale nutrient cycling dynamics. Warming-induced increases in decomposition and the associated $\mathrm{C}$ and nutrient loss along with declining permafrost are a stark example of consequences of a climate-induced biome shift.

\section{Temperature and Precipitation as Determinants of Ecosystem Productivity}

Temperature and precipitation, along with $\mathrm{N}$ and $\mathrm{P}$ availability, are primary factors limiting terrestrial ecosystem productivity at local, regional, and global scales. Ecosystem productivity generally increases along geographic gradients of increasing temperature and precipitation (Kang et al. 2006; Raich et al. 2006; Wu et al. 2011). These changes in ecosystem productivity influence the amount and distribution of aboveground and belowground plant biomass and alter the flow of $\mathrm{C}$ and nutrients as these elements flux between the soils, microbiota, and vegetation. Soil C, for example, has been shown to increase along the same geographic gradients of increasing temperature and precipitation as plant productivity (Callesen et al. 2003). An increase in plant uptake associated with increased productivity can reduce leaching of nutrients to surface waters or gaseous loss of $\mathrm{N}$ compounds $\left(\mathrm{N}_{2} \mathrm{O}\right.$ and $\left.\mathrm{N}_{2}\right)$; conversely, a decrease in productivity can make nutrients vulnerable to loss through these same pathways.

\section{Temperature and Precipitation as Drivers of Physical, Chemical, and Biological Reactions}

At the molecular level, temperature and moisture are fundamental drivers of virtually all biological, chemical, and physical reactions, and any change in temperature and precipitation associated with changing climate or weather will have both direct and indirect effects on the cycling of elements in soils (Rustad and Norby 2002). Biological reactions, such as those associated with plant and microbial metabolic processes, are particularly sensitive to changes in both temperature and moisture.

Rates of reactions typically increase exponentially with an increase in temperature, up to a temperature optima, after which they decline precipitously. The decline in reaction rates at temperatures beyond the optimum is often attributed to the denaturation of biological enzymes that occurs at high temperatures $\left(>40^{\circ} \mathrm{C}\right)$. Although these high temperatures are typically found outside the thermal regime of most soils in the United States, they do occur in hot, arid ecoregions, and they may increasingly occur during hot spells associated with a warming climate (Box 4.2) or for short periods of time following site disturbance (Waide et al. 1988). If not limited by other factors such as nutrient supply, water, or toxins, the rates of biological soil nutrient cycling processes will generally be enhanced as temperature increases. This has been corroborated by long-term field research studies as well as experimental manipulations of soil and air temperatures (Rustad et al. 2001; Wu et al. 2011).

In temperate and boreal ecosystems, increases in temperatures are also advancing the dates of bud break and canopy leaf out, delaying dates of leaf senescence and leaf fall, and 
overall expanding the length of the growing season. All of these increase the amount of time that plants and microbes are actively cycling soil nutrients. In snow-dominated regions, the number of days with snow cover, the maximum snow depth, and the snow water equivalent are all declining (Box 4.2). Although there is increasing recognition that biological activity occurs under the snowpack (Brooks et al. 1995; Edwards et al. 2007), most of soil biological activity occurs at temperatures above approximately $4{ }^{\circ} \mathrm{C}$, and thus the longer that soil temperatures are above $4{ }^{\circ} \mathrm{C}$, the greater the biological activity and greater the rates of overall nutrient cycling.

The decline or loss of snowpack also has a surprising contradictory impact. Because snow acts as an effective insulator of soils, warmer winters with less snow may ironically result in colder soils with a greater frost depth, leading to colder soils in a warmer world (Groffman et al. 2001a). Greater soil freezing can result in damage to fine roots, decreases in plant uptake, and increased leaching of $\mathrm{N}$ and nutrients to surface waters (Comerford et al. 2013; Groffman et al. 2001b). In soils with permafrost (defined as soils with subsurface material that remains below $0{ }^{\circ} \mathrm{C}$ for at least 2 consecutive years), the increase in temperature can cause melting of these historically frozen soils, which will potentially release large amounts of stored $\mathrm{C}$ (as the greenhouse gases $\mathrm{CO}_{2}$ and $\mathrm{CH}_{4}$ and as dissolved organic C), $\mathrm{N}$ (as the greenhouse gases $\mathrm{N}_{2} \mathrm{O}, \mathrm{NO}$, and $\mathrm{N}_{2}$ and as dissolved organic and inorganic N), and other nutrients (Schuur et al. 2015). The warming-induced releases of greenhouse gases from historically frozen soils are a cause of great concern because this mechanism provides a powerful, positive feedback to climate change (Schuur et al. 2015). Hypothesized changes in plant growth and nutrient cycling associated with lengthening of growing seasons, declines in extent and duration of snowpacks, and melting of permafrost have been corroborated by long-term field studies as well as experimental manipulations of air and soil temperatures and of the snowpack (Arft et al. 1999; Comerford et al. 2013; Groffman et al. 2001b; Loik et al. 2013).

Water plays several critical roles in soil nutrient cycling. Water sustains plant, microbial, and animal life; controls soil aeration by occupying pore spaces in soils; transports soil nutrients within the soil matrix to plant roots and microsites (via diffusion and mass flow); and transports soil nutrients out of the soil and ecosystem via erosion and leaching. In soils where oxygen is not limiting, soil nutrients typically become less available under drought conditions, as microbially driven aerobic processes regulating soil nutrient cycling (e.g., decomposition, ammonification, nitrification, nitrous oxide production, and aerobic respiration) typically decline with declining moisture, particularly as soil moisture falls below critical thresholds. These same processes also decline under saturated conditions, when water fills soil pores and oxygen becomes limiting (Arnold et al. 1999; Burton et al. 1998; Davidson et al. 2008; Emmett et al. 2004; Pilbeam et al. 1993; Rey et al. 2002; Rustad et al. 2000; Schlesinger 2013; Stark and Firestone 1995; Tate et al.
1988). In hydric soils, such as those found in wetlands, soils are permanently or seasonally saturated by water, and without vigorous oxygen diffusion aided by plant aerenchyma, oxygen is limiting and anaerobic processes dominate (Brady and Weil 2013). Under these conditions, drought can actually induce more favorable conditions for aerobic microbial processes by increasing the oxygen status of the soils (Emmett et al. 2004). Concurrently, rates of anaerobic processes, such as methanogenesis and denitrification, may decline. Increased precipitation may have little impact on these already water-saturated soils.

Overall, even though changes in the timing, intensity, frequency, and type of precipitation have been documented at regional and continental scales, these types of changes receive less attention than changes in the total precipitation amount (Laseter et al. 2012; Melillo et al. 2014). However, as the seasonal distribution of precipitation continues to change (e.g., the monsoon season in the Southwest (Petrie et al. 2014) and the summer versus fall precipitation in the Southeast (Laseter et al. 2012)), the intensity of precipitation continues to increase (as observed in the Northeast (Melillo et al. 2014) and the high rainfall areas of the southern Appalachians (Aber et al. 1993; Laseter et al. 2012)), the frequency of precipitation changes (e.g., projected longer periods between larger rain events for the Northeast (Melillo et al. 2014)), and more precipitation falls as rain or mixed precipitation than snow (as observed in the long-term record at the Hubbard Brook Experimental Forest (Likens 2013)), understanding these impacts on forest and rangeland nutrient cycling dynamics will become increasingly important.

In summary, the short-term changes in weather and longerterm changes in climate that have been observed in the United States over the past century (Melillo et al. 2014) have affected soil nutrients, and these changes along with changes that are projected for the future (IPCC 2014) will continue to have profound effects on forest and rangeland nutrient cycles.

\section{Extreme Disturbance}

Extreme natural and anthropogenic ecosystem disturbances, such as wildland fires, drought, mining of minerals, extraction of fossil fuels, and urbanization, are affecting an increasingly larger portion of the landscape. These events can lead to catastrophic disruptions of nutrient cycling within the forests and rangelands. Potential disturbances and their impacts are discussed in greater detail in Chaps. 2 and 3.

\section{Invasive Species, Insect Pests, and Pathogens}

A discussion of human-induced impacts on forest and rangeland biogeochemical cycling would be incomplete without a discussion of invasive species, insect pests, and pathogens. The 
impacts of these organisms occur both aboveground and belowground. Aboveground impacts can cause defoliation, tree stress, tree decline and mortality, and plant species extirpation; belowground impacts can cause organic and mineral soil disturbance, changes in amount and chemistry of litter inputs, fine root mortality, changes in bulk density, and changes in amount and composition of organic matter (Ayres and Lombardero 2000; Dukes et al. 2009; Lovett et al. 2010). Escalation of impacts from these combined "nuisance" species is expected to continue under future population, land use, and climate scenarios, so these disturbance factors remain an area of concern for land managers and the public (Dukes et al. 2009).

\section{Invasive Species}

An invasive species has been defined as "a species that is nonnative to the ecosystem under consideration and whose introduction causes or is likely to cause economic or environmental harm or harm to human health" (Beck et al. 2008). Invasive species that impact forest and rangeland nutrient cycles include invasive plants, insects, annelids, and other animals.

Invasive nonnative plant species impact native vegetation through competition for space, water, and nutrients. In some instances, an infestation by invasive plant species can result in the complete (or nearly complete) mortality of a foundational species (Ellison et al. 2005). In all instances, new species assemblages will alter element cycles, although the specific response varies with the invasive species and the ecosystem. A few examples of invasive plant species include kudzu (Pueraria montana), Oriental bittersweet (Celastrus orbiculatus), English ivy (Hedera helix), Canada thistle (Cirsium arvense), and sweet clover (Melilotus officinalis). Kudzu, introduced to the United States in the 1870s to reduce soil erosion, is a particularly virulent invasive plant species. Since its introduction, it has spread to over three million ha (Forseth and Innis 2004) and continues to spread at a rate of 50,000 ha per year (Hickman et al. 2010). Kudzu is an invasive vine that climbs on existing forest vegetation, adding a structural component to growth suppression (Fig. 4.6). It

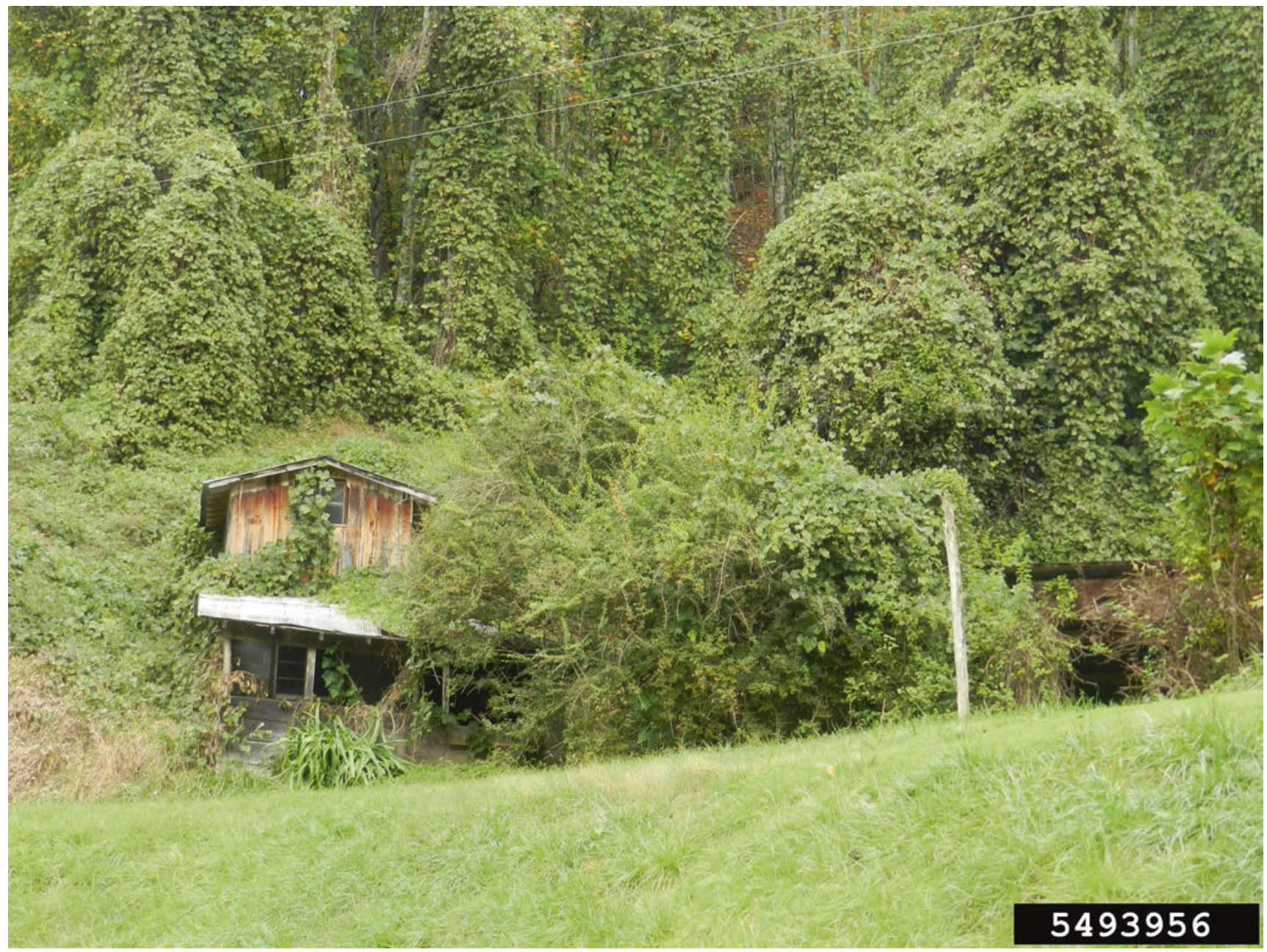

Fig 4.6 Kudzu, a fast-growing invasive plant species, can overgrow and shade out native vegetation (Photo credit: Jerry Asher, USDI Bureau of Land Management, via Bugwood.org) 
also emits isoprenes, organic molecules that inhibit plant growth. Kudzu spreads rapidly due to the rooting potential of stems, high photosynthetic rate, high water use capacity, and its ability to fix atmospheric $\mathrm{N}$. This increases $\mathrm{N}$ inputs to the soil, which can result in elevated $\mathrm{N}$ leaching to streams and increased $\mathrm{N}_{2} \mathrm{O}$ (a potent greenhouse gas) emissions from the soil to the atmosphere (Hickman et al. 2010). Kudzu's positive growth response to temperature suggests that its range will continue to expand in the future.

Introduced, nonnative insects and annelids, such as beetles, termites, and earthworms (suborder Lumbrica), can have profound impacts on soil nutrient cycling through bioturbation and transformations of aboveground vegetation and soil organic matter. A few examples of these species include Asian long-horned beetle (Anoplophora glabripennis), Formosan subterranean termite (Coptotermes formosanus), red imported fire ant (Solenopsis invicta), and earthworms (Lumbricus terrestris).

Earthworms play a particularly important role in soil formation processes and C cycling (Edwards 2004). Fahey and others (2013), for example, showed that in forests of the Northeast and Central United States, the introduction of nonnative earthworms reduced soil C storage in the upper $20 \mathrm{~cm}$ of the soil profile by $37 \%$, leading to dramatic reductions in O-horizon organic matter and redistributions of nutrients within the soil profile.

Introduced, nonnative animals can alter both aboveground and belowground element cycling. Wild hogs (Sus scrofa), for example, are a common invasive species in the United States, representing a mix of European wild boar released for hunting in the 1940s and feral domestic hogs. Wild hogs reproduce at a high rate and have considerable negative impact on native plants and rates of decomposition and nutrient cycling. Research in the Great Smoky Mountains National Park (located in North Carolina and Tennessee) found that hogs caused considerable damage to the herbaceous layer plants, but not overstory species. Their activities increased turnover and rates of decomposition of the $\mathrm{O}$ horizon and increased leaching of $\mathrm{N}$ into streams adjacent to areas disturbed by hog activity (Bratton 1975).

\section{Insect Pests}

Both the introduction of new insect pests and changes in range or virulence of native insect pests can also have dramatic impacts on forest and rangeland biogeochemical cycling. Examples of insect pests include forest tent caterpillar (Malacosoma disstria), gypsy moth (Lymantria dispar), spruce budworm (Choristoneura fumiferana), southern pine beetle (Dendroctonus frontalis), Asian long-horned beetle, and emerald ash borer (Agrilus planipennis). These insects are increasing in abundance and virulence, as ranges expand in response to increasing minimum temperatures and to increased host sensitivity due to larger areas of forests and grasslands being under stress from other factors such as heat, drought, and air pollution. An example on the East Coast is the hemlock woolly adelgid (Adelges tsugae), which was introduced into the United States in the 1950s. After a slow initial expansion, the adelgid has moved rapidly northward in response to an increase in minimum winter temperature and now occupies most of the range of eastern Hemlock (Tsuga canadensis) (Knoepp et al. 2011). Impacts of the adelgid on pure stands of hemlock common in the northeastern United States resulted in increased soil N (Orwig et al. 2008), while in the mixed stands of the Southern Appalachians, there were no initial changes in $\mathrm{N}$ cycling (Knoepp et al. 2011) due to the dominance of a native evergreen shrub in the understory (Elliott et al. 2016; Ford et al. 2012). Forests without the evergreen shrub showed an increase in both $\mathrm{N}$ and $\mathrm{P}$ cycling (Block et al. 2012, 2013).

An example of an insect pest that has expanded its range on the West Coast is the mountain pine beetle (Dendroctonus ponderosae). The range of this native insect of pine (Pinus spp.) forests in western North America has historically extended from Mexico to Canada and at elevations from sea level to $3353 \mathrm{~m}$. With an increase in winter low temperatures and increased climate-change-related stress to host trees, the mountain pine beetle has expanded its range to the Northeast and upwards in elevation. Western coniferous forests, mostly in Wyoming, Montana, Colorado, and Idaho, have been ravaged by this insect pest.

\section{Pathogens}

Pathogens are also increasing in virulence, particularly as conditions become warmer and wetter and the abundance of stressed trees, forests, and grasslands increases (Sturrock et al. 2011). A few examples of pathogens include chestnut blight (Cryphonectria parasitica), beech bark disease (Cryptococcus fagisuga/Neonectria spp. complex), sudden oak death (Phytophthora ramorum), and root rot fungus (Armillaria mellea). An example of the devastating impact of a forest pathogen is the infection of the American chestnut (Castanea dentata) by chestnut blight in the 1920s and 1930s, which reshaped American forests across the eastern United States (Elliott and Swank 2008). The loss of chestnut resulted in changes in tree species composition, and while there was certainly a shift in forest biogeochemical cycling, the effects are unknown due to lack of research at that time. More recently, the impact of beech bark disease on forests in the Catskill Mountains of the northeastern 
United States was examined by Lovett and others (2010). This disease resulted in the decline of American beech (Fagus grandifolia) followed by an increase in sugar maple. The result was an increase in rates of litter decomposition and increased soil $\mathrm{N}$ and $\mathrm{N}$ leaching (Lovett et al. 2010).

\section{Key Findings}

- Maintaining forest and rangeland nutrient pools and cycles is essential to supporting healthy and productive ecosystems. We have learned that intentional actions from forest and rangeland management; unintended consequences of point and nonpoint source pollutants; changes in climate and weather; extreme events such as wildfire, mining, and urbanization; and increases in the distribution and abundance of pests, pathogens, and invasive species have significantly altered forest and rangeland nutrient cycles across the sweep of American history. We anticipate more changes to come. Some of these future changes are predictable; other changes are unpredictable or as yet unknown. In the face of these changes, it is important to be proactive rather than reactive in maintaining forest and rangeland nutrient cycles. We must act before soils are degraded or altered in new ways, as the cost of remediation far exceeds the cost of proactive management.

\section{Key Information Needs}

- The nature and dynamics of soil organic matter-Our view on the nature and dynamics of soil organic matter continues to evolve. A few decades back, most soil scientists were comfortable in their explanations for why soils contain organic matter. The theory was that some of the material in plant tissues was recalcitrant to decomposition and that some of the by-products of decomposition included complex organic molecules resistant to degradation (i.e., humic substances). The current state of knowledge, however, is shifting as it acknowledges that short-term decomposition of plant materials (over several years or a decade) gives little insight into the processes that regulate the longer-term accumulation and loss of soil organic matter. More startling is the recognition that complex chains of organic molecules may not be common in soils and the apparent dominance of humic compounds may in part be an artifact of the chemicals used in processing soils (Schmidt et al. 2011). The current view of soil organic matter accumulation and loss from soils no longer focuses on molecules that are unusually resistant to decay. The focus is now on complex interactions of soil structure, which can physically protect molecules from decay (Six et al. 2006; Torn et al. 1997), and interactions with minerals, many of which are redox sensitive and whose availability and oxidation state may change with a changing climate. A great deal of work will be needed to challenge or support the emerging views of soil organic matter (Schmidt et al. 2011). Forest soil scientists will need to pay special attention to soil horizons because the dynamics of $\mathrm{O}$ horizons at the top of soil profiles may be very different from the dynamics that characterize mineral soil horizons, where most of the organic matter resides. Understanding these dynamics will take a combination of long-term field experiments with periodic sampling and archiving of samples. These kinds of studies are not common, but there are several successful examples of long-term soil-ecosystem experiments with periodic sampling that are ongoing (Lawrence et al. 2013; Richter et al. 2007).

- Mineral weathering - The history of the science on mineral weathering is somewhat different than soil organic matter in that the science of mineral weathering has long existed in a state of uncertainty. While scientists have been certain in their understanding that mineral weathering is a major source of nutrients entering nutrient cycles (as was so elegantly stated by Leopold (1949) in our introduction), we have not had the ability to quantitatively estimate rates of mineral weathering. New conceptual models and interdisciplinary research teams (e.g., teams that have gathered for critical zone science), new and transformative instrumentation, and new uses of longterm forest research sites will be needed to provide future quantitative estimations of mineral weathering (Richter and Billings 2015).

- Changes in soil biogeochemistry over time-Better understanding of soil organic matter and mineral weathering will complement some of the most important lessons from soil science over the past 200 years-that soils vary greatly across landscapes and over time. We have a very good understanding of the changes in soils across landscapes, including valuable surveys produced at the county level by the USDA Natural Resources Conservation Service. Knowledge about changes over time is not nearly as strong, and we need to know much more about how forest and rangeland soils change over time, including how the rates of change vary among nutrients and among types of soils, and how management activities influence those rates. A powerful, two-pronged approach for filling in these gaps in knowledge is to study forest and rangeland nutrient cycles intensively at long-term research sites while also making periodic observations of soil change.

- Investment in long-term research and monitoring-The United States is a world leader in supporting long-term field studies, with large multiagency, multigenerational 
networks of research sites such as the USDA Forest Service's Experimental Forest and Ranges; USDA Agricultural Research Service's Long-Term Agroecosystem Research sites; and National Science Foundation's Long-Term Ecological Research sites, National Ecological Observatory Network, and Critical Zone Observatory sites. These research efforts need to be sustained, along with being augmented by new opportunities for integrating knowledge across programs. In addition, it will be important to maintain or develop less-intensive monitoring of soil conditions across many sites because the number of intensive sites does not provide the statistical power needed to extrapolate to actual forest and rangeland soils across landscapes. In particular, developing systematic approaches to soil resampling programs across gradients of natural and human-impacted landscapes will likely be an essential tool for an effective environmental monitoring and assessment (Lawrence et al. 2013). New ways of supporting these long-term research sites are needed, perhaps in new public-private partnerships.

- Investment in human capital-Finally, in order to continue to investigate past, current, and future changes in forest and rangeland nutrient cycles, it is critical to invest in human capital by educating forest and rangeland soil scientists. We are losing academic departments, industries, and federal, state, and private jobs that have focused on the science of soils and nutrient cycling. Rather than only building up what we had in the past, we need to channel new support to successful departments and positions, as well as enhance networking opportunities among sites, scientists, and agencies with the goal to form a more cohesive national interorganizational task force on understanding and protecting forest and rangeland nutrient pools and cycles.

Acknowledgments We gratefully acknowledge the contributions from Dan Binkley on the early versions of the manuscript, the astute editing assistance of Linda Geiser and Casey Johnson, and graphics from Mary Zambello.

\section{Literature Cited}

Aber JD, Nadelhoffer KJ, Steudler P, Melillo JM (1989) Nitrogen saturation in northern forest ecosystems. Bioscience 39(6):378-386

Aber JD, Magill A, Boone R et al (1993) Plant and soil responses to chronic nitrogen additions at the Harvard Forest. Massachusetts. Ecol Appl 3:156-166

Aber J, McDowell W, Nadelhoffer K et al (1998) Nitrogen saturation in temperate forest ecosystems. Bioscience 48:921-934

Adams MB, Burger JA, Jenkins AB, Zelazny L (2000) Impact of harvesting and atmospheric pollution on nutrient depletion of eastern US hardwood forests. For Ecol Manag 138:301-319
Adams MB, Knoepp JD, Webster JR (2014) Inorganic nitrogen retention by watersheds at Fernow Experimental Forest and Coweeta Hydrologic Laboratory. Soil Sci Soc Am J 78:S84-S94

Allan C, Heyes A (1998) A preliminary assessment of wet deposition and episodic transport of total and methyl mercury from low order Blue Ridge Watersheds, S.E. U.S.A. Water Air Soil Pollut 105:573-592

Alvarez J (2012) Modeling potential productivity of loblolly pine for the Southeastern US Forest Productivity Cooperative. North Carolina State University. Ph.D. dissertation, Raleigh

Arft AM, Walker MD, Gurevitch J et al (1999) Responses of tundra plants to experimental warming: meta-analysis of the international tundra experiment. Ecol Monogr 69:491-511

Argerich A, Johnson S, Sebestyen S et al (2013) Trends in stream nitrogen concentrations for forested reference catchments across the USA. Environ Res Lett 8:014039

Arnold S, Fernandez I, Rustad L, Zibilske L (1999) Microbial response of an acid forest soil to experimental soil warming. Biol Fertil Soils 30:239-244

Augusto L, De Schrijver A, Vesterdal L, [et al.]. (2014) Influences of evergreen gymnosperm and deciduous angiosperm tree species on the functioning of temperate and boreal forests: spermatophytes and forest functioning. Biol Rev 90(2):444-466

Ayres MP, Lombardero MJ (2000) Assessing the consequences of global change for forest disturbance from herbivores and pathogens. Sci Total Environ 262:263-286

Bailey SW, Buso DC, Likens GE (2003) Implications of sodium mass balance for interpreting the calcium cycle of a forested ecosystem. Ecology 84:471-484

Bailey SW, Horsley SB, Long RR (2005) Thirty years of change in forest soils of the Allegheny Plateau, Pennsylvania. Soil Sci Soc Am J 69(3):681-690

Beck K, Zimmerman K, Schardt J et al (2008) Invasive species defined in a policy context: recommendations from the Federal Invasive Species Advisory Committee. Invasive Plant Sci Manag 1(4):414421. https://doi.org/10.1614/IPSM-08-089.1

Bernhardt ES, Rosi EJ, Gessner MO (2017) Synthetic chemicals as agents of global change. Front Ecol Environ 15:84-90

Biederman LA, Harpole WS (2013) Biochar and its effects on plant productivity and nutrient cycling: a meta-analysis. GCB Bioenergy 5(2):202-214

Binkley D, Fisher RF (2012) Ecology and management of forest soils, 4th edn. Wiley, New York, $362 \mathrm{p}$

Binkley D, Valentine D (1991) Fifty-year biogeochemical effects of green ash, white pine, and Norway spruce in a replicated experiment. For Ecol Manag 40:13-25

Binkley D, Aber J, Pastor J, Nadelhoffer K (1986) Nitrogen availability in some Wisconsin forests: comparisons of resin bags and on-site incubations. Biol Fertil Soils 2:77-82

Block CE, Knoepp JD, Elliott KJ, Fraterrigo JM (2012) Impacts of hemlock loss on nitrogen retention vary with soil nitrogen availability in the southern Appalachian Mountains. Ecosystems 15:1108-1120

Block CE, Knoepp JD, Fraterrigo JM (2013) Interactive effects of disturbance and nitrogen availability on phosphorus dynamics of southern Appalachian forests. Biogeochemistry 112:329-342

Bodí MB, Martin DA, Balfour VN et al (2014) Wildland fire ash: production, composition and eco-hydro-geomorphic effects. Earth Sci Rev 130:103-127

Boerner RE (1982) Fire and nutrient cycling in temperate ecosystems. Bioscience 32:187-192

Brady NC, Weil R (2013) The nature and properties of soils. Pearson new international edition. Pearson Education, Hoboken

Bratton SP (1975) The effect of the European wild boar, Sus scrofa, on gray beech forest in the Great Smoky Mountains. Ecology 56(6):1356-1366 
Brooks PD, Williams MW, Walker D, Schmidt SK (1995) The Niwot Ridge snowfence experiment: biogeochemical responses to changes in the seasonal snowpack. In: Tonnessen KA, Williams MW, Tranter $M$ (eds) Biogeochemistry of seasonally snow covered basins, IAHS-AIHS Publ. 228. International Association of Hydrological Sciences, Wallingford, pp 293-302

Buol SW, Southard RJ, Graham RC, McDaniel PA (2011) Soil genesis and classification, 6th edn. Wiley, New York, $544 \mathrm{p}$

Burger J, Pritchett W (1984) Effects of clearfelling and site preparation on nitrogen mineralization in a southern pine stand 1. Soil Sci Soc Am J 48:1432-1437

Burns DA, Blett T, Haeuber R, Pardo LH (2008) Critical loads as a policy tool for protecting ecosystems from the effects of air pollutants. Front Ecol Environ 6:156-159

Burton AJ, Pregitzer KS, Zogg GP, Zak DR (1998) Drought reduces root respiration in sugar maple forests. Ecol Appl 8:771-778

Caliman FA, Gavrilescu M (2009) Pharmaceuticals, personal care products and endocrine disrupting agents in the environment-a review. Clean Soil Air Water 37(4-5):277-303

Callesen I, Liski J, Raulund-Rasmussen K et al (2003) Soil carbon stores in Nordic well-drained forest soils-relationships with climate and texture class. Glob Chang Biol 9:358-370

Camill P (2005) Permafrost thaw accelerates in boreal peatlands during late-20th century climate warming. Clim Chang 68:135-152

Carpi A, Fostier AH, Orta OR et al (2014) Gaseous mercury emissions from soil following forest loss and land use changes: field experiments in the United States and Brazil. Atmos Environ 96:423-429

Certini G (2005) Effects of fire on properties of forest soils: a review. Oecologia 143:1-10

Clean Air Act of 1970, as amended November 1990; 42 U.S.C. s/s 7401 et seq.; Public Law 101-549. November 15, 1990

Cole D, Rapp M (1981) Elemental cycling in forest ecosystems. Dyn Properties For Ecosyst 23:341-409

Comerford DP, Schaberg PG, Templer PH et al (2013) Influence of experimental snow removal on root and canopy physiology of sugar maple trees in a northern hardwood forest. Oecologia 171:261-269

Copeland C, Library of Congress, Congressional Research Service (1993) Clean Water Act reauthorization. Library of Congress, Congressional Research Service, Washington, DC

Davidson EA, Nepstad DC, Ishida FY, Brando PM (2008) Effects of an experimental drought and recovery on soil emissions of carbon dioxide, methane, nitrous oxide, and nitric oxide in a moist tropical forest. Glob Chang Biol 14:2582-2590

DeHayes DH, Schaberg G, Hawley GJ, Strimbeck GR (1999) Acid rain impacts on calcium nutrition and forest health. Bioscience 49(10):789-800

DeLuca T, MacKenzie M, Gundale M, Holben W (2006) Wildfireproduced charcoal directly influences nitrogen cycling in ponderosa pine forests. Soil Sci Soc Am J 70:448-453

D'Odorico P, Fuentes JD, Pockman WT et al (2010) Positive feedback between microclimate and shrub encroachment in the northern Chihuahuan desert. Ecosphere 1:1-11

Doerr-MacEwen NA, Haight ME (2006) Expert stakeholders' views on the management of human pharmaceuticals in the environment. Environ Manag 38:853-866

Dukes JS, Pontius J, Orwig D et al (2009) Responses of insect pests, pathogens, and invasive plant species to climate change in the forests of northeastern North America: what can we predict? Can J For Res 39:231-248

Duvigneaud P, Danaeyer-de Smet S (1970) Biological cycling of minerals in temperate zone forests. Analysis of temperate forest ecosystems. Springer-Verlag, New York, pp 119-205

Edwards CA (2004) Earthworm ecology, 2nd edn. CRC Press, Boca Raton, $456 \mathrm{p}$

Edwards AC, Scalenghe R, Freppaz M (2007) Changes in seasonal snow cover of alpine regions and its effect on soil processes: a review. Quat Int 162-163:172-181
Elliott KJ, Swank WT (2008) Long-term changes in forest composition and diversity following early logging (1919-1923) and the decline of American chestnut (Castanea dentata). Plant Ecol 197(2):155-172

Elliott KJ, Hendrick RL, Major AE et al (1999) Vegetation dynamics after a prescribed fire in the southern Appalachians. For Ecol Manag 114:199-213

Elliott K, Miniat CF, Knoepp J et al (2016) Restoration of southern Appalachian riparian forest affected by eastern hemlock mortality. In: Stringer CE, Krauss KW, Latimer JS (eds) Headwaters to estuaries: advances in watershed science and managementproceedings of the fifth interagency conference on research in the watersheds, e-Gen. Tech. Rep. SRS-GTR-211. U.S. Department of Agriculture, Forest Service, Southern Research Station, Asheville, p 285

Ellison AM, Bank MS, Clinton BD et al (2005) Loss of foundation species: consequences for the structure and dynamics of forested ecosystems. Front Ecol Environ 3:479-486

Emmett BA, Beier C, Estiarte M et al (2004) The response of soil processes to climate change: results from manipulation studies of shrublands across an environmental gradient. Ecosystems 7:625-637

Fahey TJ, Yavitt JB, Sherman RE et al (2013) Earthworms, litter and soil carbon in a northern hardwood forest. Biogeochemistry 114:269-280

Federer CA, Hornbeck JW, Tritton LM et al (1989) Long-term depletion of calcium and other nutrients in eastern U.S. forests. Environ Manag 13:593

Fernandez IJ, Rustad LE, Norton SA et al (2003) Experimental acidification causes soil base-cation depletion at the Bear Brook Watershed in Maine. Soil Sci Soc Am J 67:1909-1919

Ford CR, Elliott KJ, Clinton BD, [et al]. (2012) Forest dynamics following eastern hemlock mortality in the southern Appalachians. Oikos 121:523-536

Forseth IN, Innis AF (2004) Kudzu (Pueraria montana): history, physiology, and ecology combine to make a major ecosystem threat. Crit Rev. Plant Sci 23:401-413

Fox TR, Allen HL, Albaugh TJ et al (2007) Tree nutrition and forest fertilization of pine plantations in the southern United States. South J Appl For 31:5-11

Frossard A, Hartmann M, Frey B (2017) Tolerance of the forest soil microbiome to increasing mercury concentrations. Soil Biol Biochem 105:162-176

Gill RA, Burke IC (1999) Ecosystem consequences of plant life form changes at three sites in the semiarid United States. Oecologia 121:551-563

Giller KE, Witter E, Mcgrath SP (1998) Toxicity of heavy metals to microorganisms and microbial processes in agricultural soils: a review. Soil Biol Biochem 30(10-11):1389-1414

Giovannini G, Lucchesi S, Giachetti M (1988) Effect of heating on some physical and chemical parameters related to soil aggregation and erodibility. Soil Sci 146:255-261

González-Pérez JA, González-Vila FJ, Almendros G, Knicker H (2004) The effect of fire on soil organic matter-a review. Environ Int 30:855-870

Gosz JR, Likens GE, Bormann FH (1972) Nutrient content of litter fall on the Hubbard Brook Experimental Forest, New Hampshire. Ecology 53(5):769-784

Groffman PM, Driscoll T, Fahey J et al (2001a) Colder soils in a warmer world: a snow manipulation study in a northern hardwood forest ecosystem. Biogeochemistry 56:135-150

Groffman PM, Driscoll CT, Fahey TJ et al (2001b) Effects of mild winter freezing on soil nitrogen and carbon dynamics in a northern hardwood forest. Biogeochemistry 56:191-213

Hayhoe K, Wake CP, Huntington TG et al (2007) Past and future changes in climate and hydrological indicators in the US Northeast. Clim Dyn 28:381-407

Heiberg SO, Madgwick H, Leaf AL (1964) Some long-time effects of fertilization on red pine plantations. For Sci 10:17-23 
Hickman JE, Wu S, Mickley LJ, Lerdau MT (2010) Kudzu (Pueraria montana) invasion doubles emissions of nitric oxide and increases ozone pollution. Proc Natl Acad Sci 107:10115-10119

Holdridge LR (1947) Determination of world plant formations from simple climatic data. Science 105:367-368

Hooper DU, Vitousek PM (1998) Effects of plant composition and diversity on nutrient cycling. Ecol Monogr 68:121-149

Hornbeck JW, Smith CT, Martin CW et al (1990) Effects of intensive harvesting on nutrient capitals of three forest types in New England. For Ecol Manag 30(1-4):55-64

Horsley SB, Long RP, Bailey SW et al (2002) Health of eastern North American sugar maple forests and factors affecting decline. North J Appl For 19:34-44

Hotchkiss S, Vitousek PM, Chadwick OA, Price J (2000) Climate cycles, geomorphological change, and the interpretation of soil and ecosystem development. Ecosystems 3:522-533

Huntington TG (2000) The potential for calcium depletion in forest ecosystems of southeastern United States: review and analysis. Glob Biogeochem Cycles 14:623-638

Huntington TG (2006) Evidence for intensification of the global water cycle: review and synthesis. J Hydrol 319:83-95

Hutchinson G (1954) The biochemistry of the terrestrial atmosphere. In: Kuiper GP (ed) The Earth as a planet. University of Chicago Press, Chicago. Chapter 8

Intergovernmental Panel on Climate Change [IPCC] (2014). Climate Change 2014: synthesis report. Contribution of Working Groups I, II and III to the Fifth Assessment Report of the Intergovernmental Panel on Climate Change (Core Writing Team, Pachauri RK, Meyer LA eds). Geneva, Switzerland. $151 \mathrm{p}$

Jenny H (1980) The soil resource, Ecological Studies 37. Springer, New York

Jerabkova L, Prescott CE, Titus GD et al (2011) A meta-analysis of the effects of clearcut and variable-retention harvesting on soil nitrogen fluxes in boreal and temperate forests. Can J For Res 41:1852-1870

Jiskra M, Wiederhold JG, Skyllberg U et al (2015) Mercury deposition and re-emission pathways in boreal forest soils investigated with hg isotope signatures. Environ Sci Technol 49:7188-7196

Johnson DW (1984) Sulfur cycling in forests. Biogeochemistry 1:29-43

Johnson DW, Curtis PS (2001) Effects of forest management on soil C and N storage: meta analysis. For Ecol Manag 140:227-238

Johnson DW, Lindberg SE (eds) (1992) Atmospheric deposition and forest nutrient cycling: a synthesis of the integrated forest study. Springer-Verlag, New York

Johnson D, Trettin C, Todd D Jr (2016) Changes in forest floor and soil nutrients in a mixed oak forest 33 years after stem only and wholetree harvest. For Ecol Manag 361:56-68

Kahl JS, Stoddard JL, Haeuber R et al (2004) Have U.S. surface waters responded to the 1990 Clean Air Act Amendments? Environ Sci Technol 38:484A-490A

Kallenborn R, Brorström-Lundén E, Reiersen L-O, Wilson S (2017) Pharmaceuticals and personal care products (PPCPs) in Arctic environments: indicator contaminants for assessing local and remote anthropogenic sources in a pristine ecosystem in change. Environ Sci Pollut Res 25:33001. https://doi.org/10.1007/ s11356-017-9726-6

Kang S, Kimball JS, Running SW (2006) Simulating effects of fire disturbance and climate change on boreal forest productivity and evapotranspiration. Sci Total Environ 362:85-102

Knapp AK, Beier C, Briske DD et al (2008) Consequences of more extreme precipitation regimes for terrestrial ecosystems. Bioscience 58:811-821

Knoepp JD, Vose JM, Swank WT (2004) Long-term soil responses to site preparation burning in the southern Appalachians. For Sci 50(4):540-550

Knoepp JD, DeBano LF, Neary DG (2005) Soil chemistry. In: Neary DG, Ryan KC, DeBano LF (eds) Wildland fire in eco- systems: effects of fire on soils and water, General Technical Report RMRS-GTR-42-vol.4. U.S. Department of Agriculture, Forest Service, Rocky Mountain Research Station, Ogden, pp 53-72

Knoepp JD, Vose JM, Clinton BD, Hunter MD (2011) Hemlock infestation and mortality: impacts on nutrient pools and cycling in Appalachian forests. Soil Sci Soc Am J 75:1935-1945

Laseter SH, Ford CR, Vose JM, Swift LW (2012) Long-term temperature and precipitation trends at the Coweeta Hydrologic Laboratory, Otto, North Carolina, USA. Hydrol Res 43:890-901

Lawrence GB, Sutherland CW, Boylen SW et al (2007) Acid rain effects on aluminum mobilization clarified by inclusion of strong organic acids. Environ Sci Technol 41:93-98

Lawrence GB, Shortle WC, David MB et al (2012) Early indications of soil recovery from acidic deposition in US red spruce forests. Soil Sci Soc Am J 76:1407-1417

Lawrence GB, Fernandez IJ, Richter DD et al (2013) Measuring environmental change in forest ecosystems by repeated soil sampling: a North American perspective. J Environ Qual 42:623-639

Lawrence GB, Hazlett PW, Fernandez IJ et al (2015) Declining acidic deposition begins reversal of forest-soil acidification in the northeastern U.S. and eastern Canada. Environ Sci Technol 49:13103-13111

Leopold A (1949) A Sand County almanac. Oxford University Press, New York

Li Y, Schichtel BA, Walker JT et al (2016) Increasing importance of deposition of reduced nitrogen in the United States. Proc Natl Acad Sci 113:5874-5879

Likens GE (1989) Some aspects of air pollutant effects on terrestrial ecosystems and prospects for the future. Ambio 18:172-178

Likens GE (2013) Biogeochemistry of a forested ecosystem, 3rd edn. Springer, New York, $208 \mathrm{p}$

Likens GE, Bormann FH (1974) Acid rain: a serious regional environmental problem. Science 184:1176-1179

Likens GE, Bormann FH (1995) Biogeochemistry of a forested ecosystem, 2nd edn. Springer-Verlag, New York, $159 \mathrm{p}$

Likens GE, Bormann FH, Johnson NM (1972) Acid rain. Environ Sci Policy Sustain Dev 14:33-40

Likens GE, Driscoll CT, Buso DC (1996) Long-term effects of acid rain: response and recovery of a forest ecosystem. Science 272:244-246

Likens GE, Driscoll CT, Buso DC et al (1998) The biogeochemistry of calcium at Hubbard Brook. Biogeochemistry 41:89-173

Likens GE, Driscoll CT, Buso DC et al (2002) The biogeochemistry of sulfur at Hubbard Brook. Biogeochemistry 60:235-316

Liu S, Munson R, Johnson D et al (1991) Application of a nutrient cycling model $(\mathrm{NuCM})$ to a northern mixed hardwood and a southern coniferous forest. Tree Physiol 9:173-184

Loik ME, Griffith AB, Alpert H (2013) Impacts of long-term snow climate change on a high-elevation cold desert shrubland, California, USA. Plant Ecol 214:255-266

Lovett GM, Goodale CL (2011) A new conceptual model of nitrogen saturation based on experimental nitrogen addition to an oak forest. Ecosystems 14:615-631

Lovett GM, Arthur MA, Weathers KC, Griffin JM (2010) Long-term changes in forest carbon and nitrogen cycling caused by an introduced pest/pathogen complex. Ecosystems 13:1188-1200

Mann LK, Johnson DW, West DC et al (1988) Effects of whole-tree and stem-only clearcutting on postharvest hydrologic losses, nutrient capital, and regrowth. For Sci 34:412-428

Matida Y, Kumada H, Kimura S et al (1971) Toxicity of mercury compounds to aquatic organisms and accumulation of the compounds by the organisms. Bull Freshwat Fish Res Lab 21:197-227

Mazur M, Mitchell C, Eckley C et al (2014) Gaseous mercury fluxes from forest soils in response to forest harvesting intensity: a field manipulation experiment. Sci Total Environ 496:678-687

McCullough DG, Werner RA, Neumann D (1998) Fire and insects in northern and boreal forest ecosystems of North America. Annu Rev Entomol 43:107-127 
McNulty SG, Cohen EC, Moore Myers JA et al (2007) Estimates of critical acid loads and exceedances for forest soils across the conterminous United States. Environ Pollut 149:281-292

Melillo JM, Richmond TC, Yohe GW (eds) (2014) Climate change impacts in the United States: the third national climate assessment. U.S. Global Change Research Program, Washington, DC, 841 p

Mitchell MJ, Likens GE (2011) Watershed sulfur biogeochemistry: shift from atmospheric deposition dominance to climatic regulation. Environ Sci Technol 45(12):5267-5271

Mobley ML, Lajtha K, Kramer MG et al (2015) Surficial gains and subsoil losses of soil carbon and nitrogen during secondary forest development. Glob Chang Biol 21:986-996

Nave L, Vance E, Swanston C, Curtis P (2010) Harvest impacts on soil carbon storage in temperate forests. For Ecol Manag 259(5):857e866

Neary DG, Klopatek CC, DeBano LF, Ffolliott PF (1999) Fire effects on belowground sustainability: a review and synthesis. For Ecol Manag 122:51-71

Nilsson J (1988) Critical loads for Sulphur and nitrogen. Air pollution and ecosystems. Springer, New York, pp 85-91

Nilsson J, Grennfelt P (eds) (1988) Critical loads for Sulphur and nitrogen. NORD 97. Copenhagen, Nordic Council of Ministers, $418 \mathrm{p}$

Odén, S. (1968) The acidification of air and precipitation and its consequences in the natural environment. Swedish National Science Research Council, Ecology Committee. Bull. 1. (In Swedish). $68 \mathrm{p}$

Orwig DA, Cobb RC, D'Amato AW et al (2008) Multi-year ecosystem response to hemlock woolly adelgid infestation in southern New England forests. Can J For Res 38:834-843

Ovington J (1962) Quantitative ecology and the woodland ecosystem concept. Adv Ecol Res 1:103-192

Pardo LH, Fenn ME, Goodale L et al (2011) Effects of nitrogen deposition and empirical nitrogen critical loads for ecoregions of the United States. Ecol Appl 21:3049-3082

Parmesan C, Yohe G (2003) A globally coherent fingerprint of climate change impacts across natural systems. Nature 421:37

Patra M, Sharma A (2000) Mercury toxicity in plants. Bot Rev 66:379-422

Payette S, Delwaide A, Caccianiga M, Beauchemin M (2004) Accelerated thawing of subarctic peatland permafrost over the last 50 years. Geophys Res Lett 31:L18208

Petrie MD, Collins SL, Gutzler DS, Moore DM (2014) Regional trends and local variability in monsoon precipitation in the northern Chihuahuan Desert. J Arid Environ 103:63-70

Pilbeam C, Mahapatra B, Wood M (1993) Soil matric potential effects on gross rates of nitrogen mineralization in an Orthic Ferralsol from Kenya. Soil Biol Biochem 25:1409-1413

Prescott CE (2002) The influence of the forest canopy on nutrient cycling. Tree Physiol 22:1193-1200

Raich JW, Russell AE, Kitayama K et al (2006) Temperature influences carbon accumulation in moist tropical forests. Ecology 87:76-87

Rashid A, Ryan J (2004) Micronutrient constraints to crop production in soils with Mediterranean-type characteristics: a review. J Plant Nutr 27:959-975

Reich PB, Grigal DF, Aber JD, Gower ST (1997) Nitrogen mineralization and productivity in 50 hardwood and conifer stands on diverse soils. Ecology 78:335-347

Rey A, Pegoraro E, Tedeschi V et al (2002) Annual variation in soil respiration and its components in a coppice oak forest in Central Italy. Glob Chang Biol 8:851-866

Rice KC, Scanlon TM, Lynch JA, Cosby BJ (2014) Decreased atmospheric sulfur deposition across the southeastern US: when will watersheds release stored sulfate? Environ Sci Technol 48:10071-10078

Richter DD (2007) Humanity's transformation of Earth's soil: pedology's new frontier. Soil Sci 172(12):957-967

Richter DD, Billings SA (2015) 'One physical system': Tansley's ecosystem as Earth's critical zone. New Phytol 206:900-912
Richter DD Jr, Markewitz D (2001) Understanding soil change: soil sustainability over millennia, centuries, and decades. Cambridge University Press, New York, $255 \mathrm{p}$

Richter DD, Yaalon DH (2012) "The changing model of soil” revisited. Soil Sci Soc Am J 76:766-778

Richter DD, Ralston CW, Harms WR (1982) Prescribed fire: effects on water quality and forest nutrient cycling. Science 215:661-663

Richter DD, Hofmockel M, Callaham MA et al (2007) Long-term soil experiments: keys to managing Earth's rapidly changing ecosystems. Soil Sci Soc Am J 71:266-279

Rustad L, Norby R (2002) Temperature increase: effects on terrestrial ecosystems. Encyc Glob Environ Chang 2:575-581

Rustad LE, Huntington TG, Boone RD (2000) Controls on soil respiration: implications for climate change. Biogeochemistry 48:1-6

Rustad LE, Campbell JL, Marion GM et al (2001) A meta-analysis of the response of soil respiration, net nitrogen mineralization, and aboveground plant growth to experimental warming. Oecologia 126(4):543-562

Schlesinger WH (2013) An estimate of the global sink for nitrous oxide in soils. Glob Chang Biol 19:2929-2931

Schmidt MW, Torn MS, Abiven S et al (2011) Persistence of soil organic matter as an ecosystem property. Nature 478:49

Schuur EAG, McGuire AD, Schadel C et al (2015) Climate change and the permafrost carbon feedback. Nature 520:171-179

Scott DA, Dean TJ (2006) Energy trade-offs between intensive biomass utilization, site productivity loss, and ameliorative treatments in loblolly pine plantations. Biomass Bioenergy 30:1001-1010

Shortle WC, Smith KT (1988) Aluminum-induced calcium deficiency syndrome in declining red spruce. Science 240:1017-1018

Six J, Frey SD, Thiet RK, Batten KM (2006) Bacterial and fungal contributions to carbon sequestration in agroecosystems. Soil Sci Soc Am J 70:555

Smith MD (2011) An ecological perspective on extreme climatic events: a synthetic definition and framework to guide future research. J Ecol 99:656-663

Stark JM, Firestone MK (1995) Mechanisms for soil moisture effects on activity of nitrifying bacteria. Appl Environ Microbiol 61:218-221

Stone E (1975) Effects of species on nutrient cycles and soil change. Philos Trans R Soc Lond B 271:149-162

Strahm BD, Harrison RB (2007) Mineral and organic matter controls on the sorption of macronutrient anions in variable-charge soils. Soil Sci Soc Am J 71:1926-1933

Sturrock RN, Frankel SJ, Brown AV et al (2011) Climate change and forest diseases. Plant Pathol 60:133-149

Suarez F, Binkley D, Kaye MW, Stottlemyer R (1999) Expansion of forest stands into tundra in the Noatak National Preserve, Northwest Alaska. Ecoscience 6:465-470

Swain EB, Engstrom DR, Brigham ME et al (1992) Increasing rates of atmospheric mercury deposition in midcontinental North America. Science 257:784-787

Swank WT, Vose JM (1993) Site preparation burning to improve southern Appalachian pine-hardwood stands: aboveground biomass, forest floor mass, and nitrogen and carbon pools. Can J For Res 23:2255-2262

Swank WT, Fitzgerald JW, Ash JT (1984) Microbial transformation of sulfate in forest soils. Science 223:182-184

Switzer G, Nelson L (1972) Nutrient accumulation and cycling in loblolly pine (Pinus taeda L.) plantation ecosystems: the first twenty years. Soil Sci Soc Am J 36:143-147

Tamm CO (1991) Nitrogen in terrestrial ecosystems. Springer-Verlag, Berlin, $116 \mathrm{p}$

Tate K, Ross D, Feltham C (1988) A direct extraction method to estimate soil microbial $\mathrm{C}$ : effects of experimental variables and some different calibration procedures. Soil Biol Biochem 20:329-335

Thiffault E, Hannam D, Paré D et al (2011) Effects of forest biomass harvesting on soil productivity in boreal and temperate forests-a review. Environ Rev 19:278-309 
Tilman D, Knops J, Wedin D et al (1997) The influence of functional diversity and composition on ecosystem processes. Science 277:1300-1302

Torn MS, Trumbore SE, Chadwick OA et al (1997) Mineral control of soil organic carbon storage and turnover. Nature 389:170

Vitousek P (1982) Nutrient cycling and nutrient use efficiency. Am Nat 119:553-572

Vitousek PM, Farrington H (1997) Nutrient limitation and soil development: experimental test of a biogeochemical theory. Biogeochemistry 37:63-75

Vitousek PM, Melillo JM (1979) Nitrate losses from disturbed forests: patterns and mechanisms. For Sci 25:605-619

Vitousek PM, Porder S, Houlton BZ, Chadwick OA (2010) Terrestrial phosphorus limitation: mechanisms, implications, and nitrogenphosphorus interactions. Ecol Appl 20:5-15

Vogt KA, Grier CC, Vogt D (1986) Production, turnover, and nutrient dynamics of above-and belowground detritus of world forests. Adv Ecol Res 15:303-377

Vose JM, Elliott KJ (2016) Oak, fire, and global change in the eastern USA: what might the future hold? Fire Ecology 12(2):160-179

Vose JM, Swank WT (1993) Site preparation burning to improve southern Appalachian pine-hardwood stands: aboveground biomass, forest floor mass, and nitrogen and carbon pools. Can J For Res 23:2255-2262

Vose JM, Swank WT, Clinton JD et al (1999) Using stand replacement fires to restore southern Appalachian pine-hardwood ecosystems: effects on mass, carbon, and nutrient pools. For Ecol Manag $114: 215-226$
Waide J, Caskey W, Todd R, Boring L (1988) Changes in soil nitrogen pools and transformations following forest clearcutting. In: Swank WT, Crossley DA Jr (eds) Forest hydrology and ecology at Coweeta. Springer-Verlag, New York, pp 221-232

Walther GR (2003) Plants in a warmer world. Perspect Plant Ecol Evol Syst 6(3):169-185

Wardle DA, Nilsson M-C, Zackrisson O (2008) Fire-derived charcoal causes loss of forest humus. Science 320:629-629

Webster J, Knoepp J, Swank W, Miniat C (2016) Evidence for a regime shift in nitrogen export from a forested watershed. Ecosystems 19(5):881-895

Wells C, Whigham D, Lieth H (1972) Investigation of mineral nutrient cycling in upland Piedmont forest. J Elisha Mitchell Sci Soc 88:66-78

Whittaker RH (1975) Communities and ecosystems, 2nd edn. Macmillan Publishing Co, New York/London

Wu Z, Dijkstra P, Koch GW et al (2011) Responses of terrestrial ecosystems to temperature and precipitation change: a metaanalysis of experimental manipulation. Global Change Biology 17:927-942

Yanai RD (1998) The effect of whole-tree harvest on phosphorus cycling in a northern hardwood forest. For Ecol Manag 104:281-295

Yanai RD, Blum JD, Hamburg SP et al (2005) New insights into calcium depletion in northeastern forests. J For 103:14-20

Yin R, Feng X, Shi W (2010) Application of the stable-isotope system to the study of sources and fate of $\mathrm{Hg}$ in the environment: a review. Appl Geochem 25:1467-1477

Open Access This chapter is licensed under the terms of the Creative Commons Attribution 4.0 International License (http://creativecommons. org/licenses/by/4.0/), which permits use, sharing, adaptation, distribution and reproduction in any medium or format, as long as you give appropriate credit to the original author(s) and the source, provide a link to the Creative Commons license and indicate if changes were made.

The images or other third party material in this chapter are included in the chapter's Creative Commons license, unless indicated otherwise in a credit line to the material. If material is not included in the chapter's Creative Commons license and your intended use is not permitted by statutory regulation or exceeds the permitted use, you will need to obtain permission directly from the copyright holder. 